\title{
GEOCHEMISTRY OF SOME QUATERNARY LAVAS FROM THE ALEUTIAN ARC AND MT. WRANGELL
}

Christopher J. Nye, James E. Begét, Paul W. Layer, Margaret T. Mangan, Vicki S. McConnell, Robert G. McGimsey, Thomas P. Miller, Richard B. Moore, and Pete Stelling

\section{Raw Data File 2018-1}

This publication is intended for the timely release of raw field and/or analytical data and does not include interpretations of the data presented. It has undergone limited internal review and does not necessarily conform to the DGGS editorial standards.

January 2018

State of Alaska

Department of Natural Resources

Division of Geological \& Geophysical Surveys

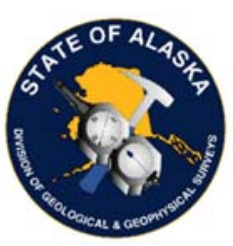




\section{STATE OF ALASKA \\ Bill Walker, Governor}

DEPARTMENT OF NATURAL RESOURCES

Andrew T. Mack, Commissioner

\section{DIVISION OF GEOLOGICAL \& GEOPHYSICAL SURVEYS}

Steve Masterman, State Geologist \& Director

Publications produced by the Division of Geological \& Geophysical Surveys are available to download from the DGGS website (dggs.alaska.gov). Publications on hard-copy or digital media can be examined or purchased in the Fairbanks office:

\section{Alaska Division of Geological \& Geophysical Surveys (DGGS)}

3354 College Road | Fairbanks, Alaska 99709-3707

Phone: 907.451 .5010 | Fax 907.451.5050

dggspubs@alaska.gov | dggs.alaska.gov

\section{DGGS publications are also available at:}

Alaska State Library, Historical

Collections \& Talking Book Center

395 Whittier Street

Juneau, Alaska 99801

Alaska Resource Library and

Information Services (ARLIS)

3150 C Street, Suite 100

Anchorage, Alaska 99503

\section{Suggested citation:}

Nye, C.J., Begét, J.E., Layer, P.W., Mangan, M.T., McConnell, V.S., McGimsey, R.G., Miller, T.P., Moore, R.B., and Stelling, P.L., 2018, Geochemistry of some quaternary lavas from the Aleutian Arc and Mt. Wrangell: Alaska Division of Geological \& Geophysical Surveys Raw Data File 2018-1, 29 p. http://doi.org/10.14509/29843

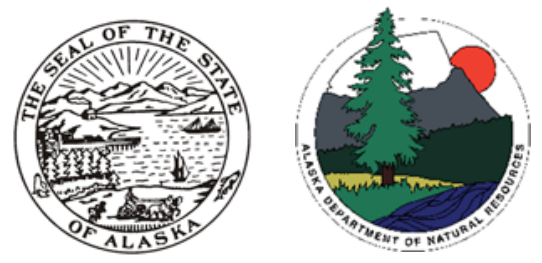




\section{GEOCHEMISTRY OF SOME QUATERNARY LAVAS FROM THE ALEUTIAN ARC AND MT. WRANGELL}

Christopher J. Nye', James E. Begét' ${ }^{2}$, Paul W. Layer ${ }^{2}$, Margaret T. Mangan ${ }^{3}$, Vicki S. McConnell ${ }^{4}$, Robert G. McGimsey ${ }^{5}$, Thomas P. Miller ${ }^{5}$, Richard B. Moore ${ }^{6}$, Pete Stelling ${ }^{7}$

\section{INTRODUCTION}

This report contains previously unpublished analyses or re-analyses of lavas, magmatic inclusions, and a few gabbroic cumulate inclusions from Alaska volcanoes collected by the authors and others over the past 35 years (see accompanying spreadsheets of geochemical analyses and applicable metadata). Table 1 lists the source volcanoes and number of analyses from each. All analyses were made by the GeoAnalytical laboratory at Washington State University in Pullman, WA. All ICP/MS data have been reduced using the 2006 calibration to ensure internal consistency of the data set despite the twenty-year span over which the analyses were made (Appendix 2). Analytical precision of the data is described in Appendix 3.

This report contains substantial data sets for three volcanoes (Vsevidof, Westdahl, and Douglas) for which little or no published data exist. Figure 1 shows the range of compositions of samples included in this report compared to Aleutian Arc data (in this report Aleutian Arc means subaerial Quaternary volcanoes of the Aleutian Islands, Alaska Peninsula, and southern Alaska that lie above the seismically-defined subducting Pacific Plate). All analyses reported here, except for the Prindle analysis, lie within the envelope of previously established Aleutian Arc geochemistry, although some are at the margins of that envelope. A brief summary of the sample set for each volcano represented in this report is given below (listed from west to east across the Arc).

\section{KISKA}

Five samples were collected for the Alaska Volcano Observatory (AVO) by members of the ornithology group from Memorial University (St. John's, Newfoundland, CA). Exact sample locations are unknown, but all come from Sirius Point on the island's northern tip or nearby. All samples are medium-K porphyritic andesites which are calcalkaline, but plot near the tholeiiticcalcalkaline dividing line. Samples were collected in 2010 and analyzed in the spring of 2011.

\footnotetext{
${ }^{1}$ Alaska Volcano Observatory, Alaska Division of Geological \& Geophysical Surveys, 3354 College Road, Fairbanks, Alaska 99709

2 Department of Geology and Geophysics, University of Alaska Fairbanks, Fairbanks, Alaska 99709

${ }^{3}$ U.S. Geological Survey, Volcano Hazards Team, MS 910, 345 Middlefield Road, Menlo Park, CA 94025

${ }^{4}$ The Geological Society of America, P.O. Box 9140, Boulder, CO 80301-91405

${ }^{5}$ Volcano Science Center-Alaska Volcano Observatory, U.S. Geological Survey, 4210 University Drive, Anchorage, Alaska 99508

${ }^{6}$ U.S. Geological Survey, retired

${ }^{7}$ Western Washington University, Department of Geology, 516 High St, MS 9080, Bellingham, WA 98225-9080
} 
Table 1. Number of analyses in this report by volcano. Volcanoes are listed from west to east.

\begin{tabular}{|c|c|c|c|c|c|}
\hline \multirow{2}{*}{ Volcano } & \multirow{2}{*}{ Latitude } & \multirow{2}{*}{ Longitude } & \multirow{2}{*}{$\begin{array}{c}\text { Major } \\
\text { elements }\end{array}$} & \multicolumn{2}{|c|}{ Trace elements } \\
\hline & & & & ICP/MS & XRF \\
\hline Kiska & 52.1031 & -182.396 & 5 & 5 & 5 \\
\hline $\begin{array}{l}\text { Unknown, near } \\
\text { Adak (Zeto Pt.) }\end{array}$ & 51.9288 & -176.553 & 6 & 6 & 6 \\
\hline $\begin{array}{l}\text { Great Sitkin } \\
\text { inclusions }\end{array}$ & 52.0765 & -176.111 & 5 & 5 & 5 \\
\hline Vsevidof & 53.1256 & -168.694 & 27 & 14 & 27 \\
\hline Recheshnoi & 53.1536 & -168.538 & 13 & 6 & 13 \\
\hline Okmok $^{1}$ & 53.4190 & -168.132 & 13 & 13 & 13 \\
\hline Akutan & 54.1331 & -165.986 & 14 & 14 & 14 \\
\hline Westdahl & 54.5171 & -164.648 & 74 & 74 & 74 \\
\hline Frosty & 55.0673 & -162.835 & 30 & 30 & 30 \\
\hline Dana & 55.6421 & -161.216 & 3 & 3 & 3 \\
\hline Ukinrek Maars & 57.8338 & -156.514 & 11 & 11 & 11 \\
\hline Kaguyak & 58.6113 & -154.025 & 1 & 1 & 1 \\
\hline Fourpeaked & 58.7703 & -153.674 & 1 & 1 & 1 \\
\hline Douglas & 58.8596 & -153.535 & 42 & 42 & 42 \\
\hline Augustine & 59.3626 & -153.435 & 25 & 25 & 25 \\
\hline Iliamna & 60.0319 & -153.092 & 25 & 25 & 25 \\
\hline Redoubt & 60.4852 & -152.744 & 74 & 56 & 74 \\
\hline Spurr ${ }^{1}$ & 61.2989 & -152.254 & 65 & 65 & 65 \\
\hline Buzzard Creek & 64.0611 & -148.432 & 3 & 3 & 3 \\
\hline Wrangell $^{1}$ & 62.0057 & -144.019 & 31 & 31 & 31 \\
\hline \multirow[t]{2}{*}{ Prindle } & 63.7136 & -141.632 & 1 & 1 & 1 \\
\hline & & total & 469 & 431 & 469 \\
\hline
\end{tabular}

\section{ADAK}

Three small domes lie on a north-northeast trending line along the shore of Adak, immediately east of Clam Lagoon and $8 \mathrm{~km}$ south-southwest of Adagdak (Coats, 1956). The dome surfaces are glacially striated and are thus pre-Holocene. Their lack of alteration or tectonic jointing suggests they are likely of Pleistocene age, although Coats (1956) suggests that they are Tertiary. Each dome is $200-300 \mathrm{~m}$ in diameter, and they are separated from each other by about $1 \mathrm{~km}$. The southern of these three domes is at Zeto Point. Samples were taken from a small roadside quarry into the northern dome in 2010, analyzed in the spring of 2011, and those analyses are included here. 
The dome has a notably high proportion of rounded magmatic inclusions up to several tens of centimeters in diameter. Three samples of the inclusions, and three samples of the host lava were analyzed.

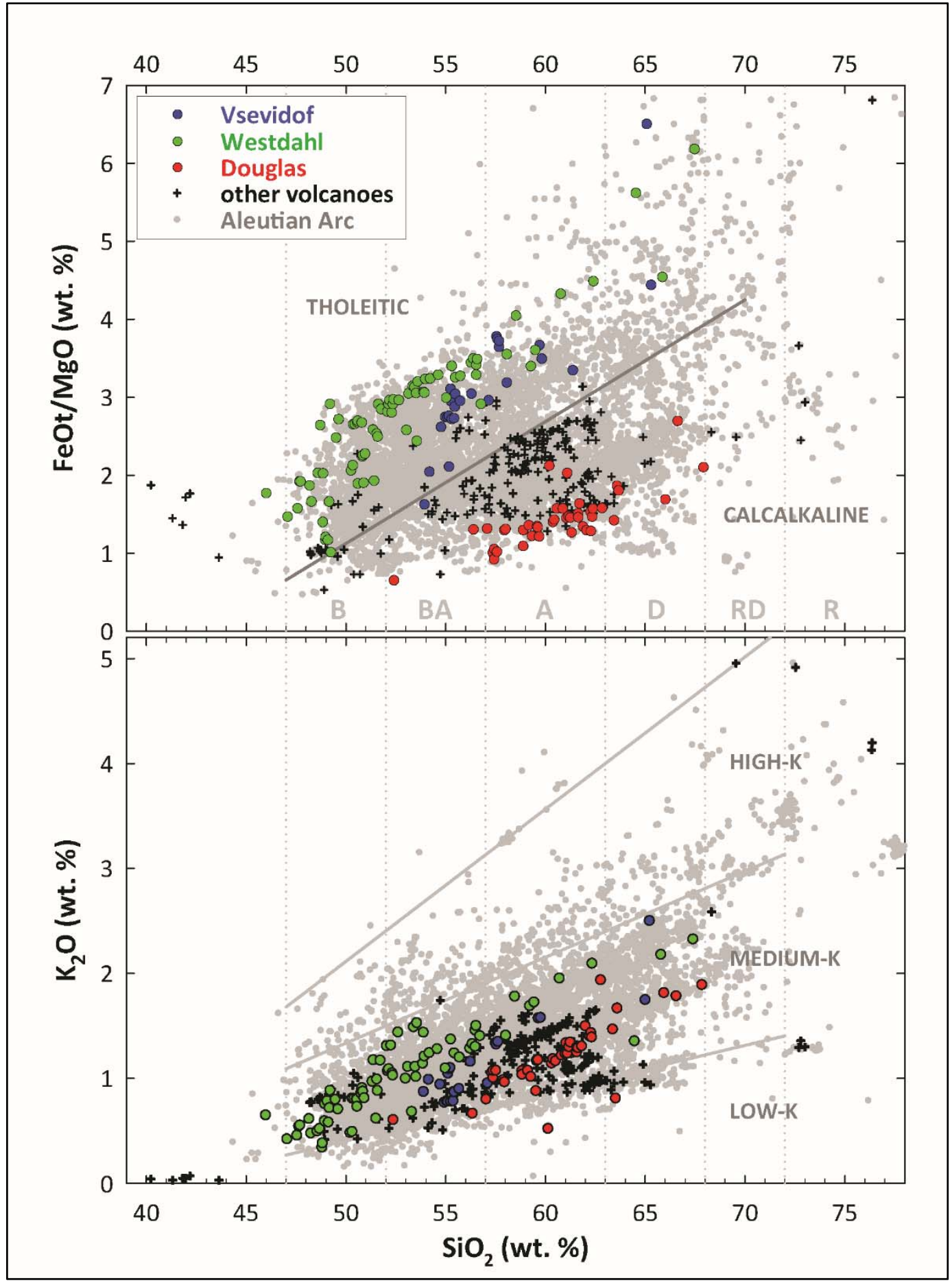

Figure 1. Summary of compositions of samples. Three volcanoes for which substantial data sets are given and that are unrepresented or poorly represented in the published literature are emphasized by colored circles. The rest of the samples in this report are shown as black crosses. Gray dots are all other analyses from the Aleutian Arc (Cameron and others, 2014). Compositions of samples from submarine vents west of the subaerial Quaternary arc (Yogodzinski and others, 2005) are not shown. 
The magmatic inclusions are variably vesicular and crystal rich ( $90-95$ vol. \% crystals on a vesicle-free basis; fig. 2). The phenocrysts consist of subequal amounts of euhedral, blocky plagioclase crystals (typically $0.4 \times 0.2 \mathrm{~mm}$ ) and euhedral prismatic to acicular amphibole crystals (typically $0.4 \mathrm{~mm}$ in diameter and up to $1.5 \mathrm{~mm}$ long) and subordinate amounts of clinopyroxene which is usually euhedral but sometimes overgrown by amphibole. There are small amounts (generally a few to several percent) of clear glass and finely crystalline groundmass.

The andesite host is strongly calcalkaline and porphyritic. Phenocrysts are dominated by amphibole, some crystals of which are completely replaced by opacite, and some of which have only thin opacite rims (fig. 2). Plagioclase phenocrysts are next most abundant, and usually contain extensive spongy regions with clear rims. Small, euhedral pyroxene phenocrysts are subordinate to plagioclase in volume. Phenocrysts make up about half the volume of the host lava. The groundmass is microcrystalline.

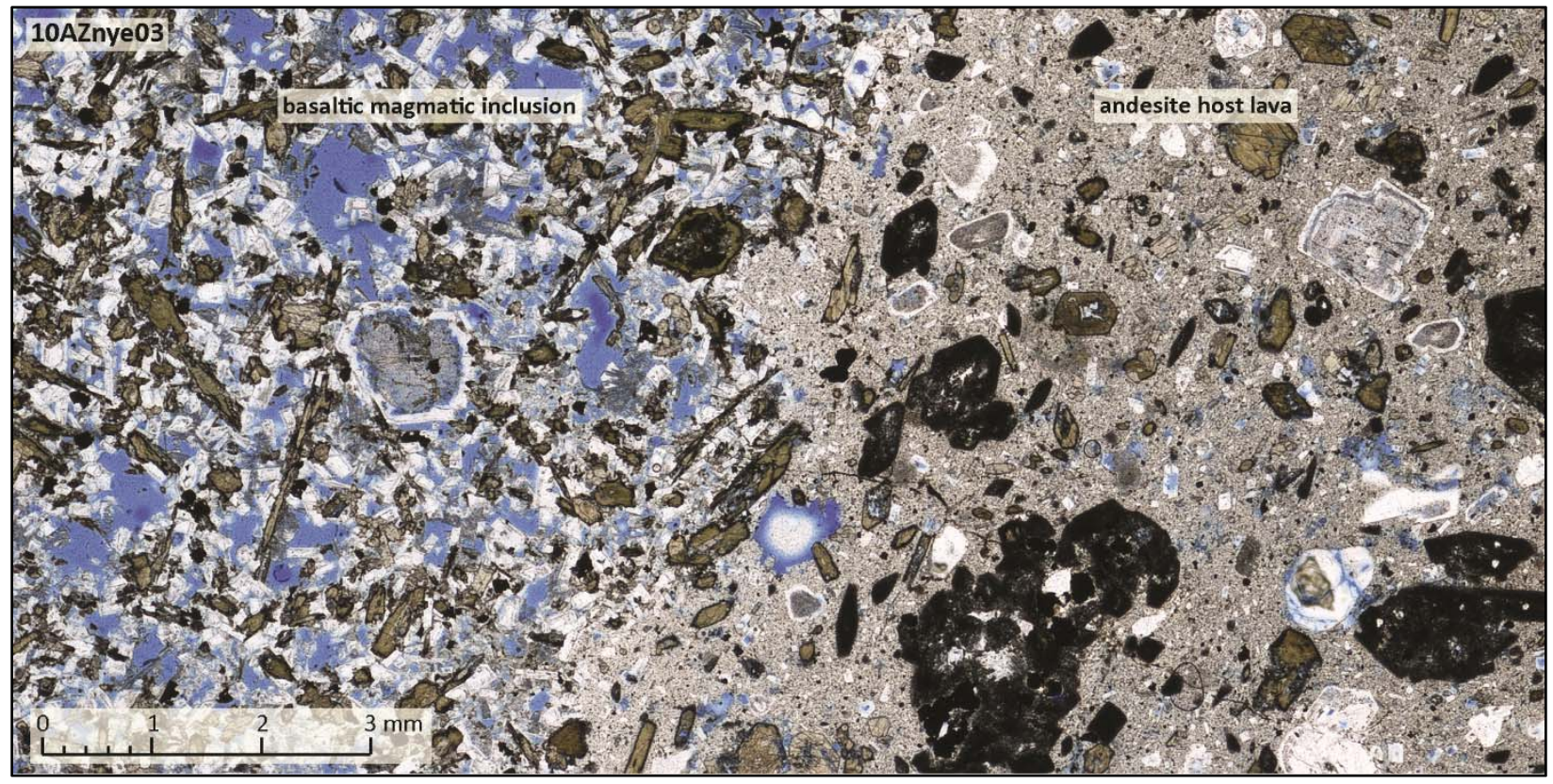

Figure 2. Plane-polarized light photomicrograph of Zeto Point sample 10AZnye03 showing the host andesite (right) and portions of a basaltic inclusion (left). Blue epoxy fills voids. Note two populations of amphibole in the andesite host-one with thin opacite rims and one where amphibole is completely replaced by opacite. In contrast, the inclusion only has amphibole with thin rims.

\section{GREAT SITKIN}

Young (300-500 yr B.P., Waythomas and others, 2003) pyroclastic deposits occupy the Glacier Creek drainage on south-west Great Sitkin Island. Juvenile clasts in the deposits are transitional tholeiitic-calcalkaline scoria spanning 51 to 59 wt. \% $\mathrm{SiO}_{2}$ (Waythomas and others, 2003). The deposits are noteworthy because they contain abundant gabbroic inclusions up to one meter in diameter. Analyses of five of the gabbroic inclusions are included here. 
The inclusions are texturally diverse, but most commonly are coarse-grained and contain unzoned anorthitic plagioclase crystals up to several millimeters in diameter and subequal proportions of amphibole poikiocrysts up to several centimeters in diameter. The inclusions have dramatically low concentrations of highly incompatible trace elements and high concentrations of $\mathrm{Al}_{2} \mathrm{O}_{3}$ and $\mathrm{CaO}$, which are hallmarks of crystalline residues of magma formation rather than slowly crystallized magmas.

\section{VSEVIDOF AND RECHESHNOI}

Twenty-seven dense lava samples were collected from the southern flank of Vsevidof by the Chris Nye and Gene Pavia in August of 1988 (fig. 3). We also collected three dense lava samples from the southwest flank of Recheshnoi. Sampling was done from a spike camp at the mouth of Black Creek established via inflatable skiff from Nikolski. Getting on to the beach at the beginning was straightforward, getting off the beach at the end was not. The sampling was done immediately after more extensive fieldwork at the Geyser Bight geothermal area (see Nye and others, [1992] and Motyka and others, [1993] for results of that work). Sample stations were located in the field

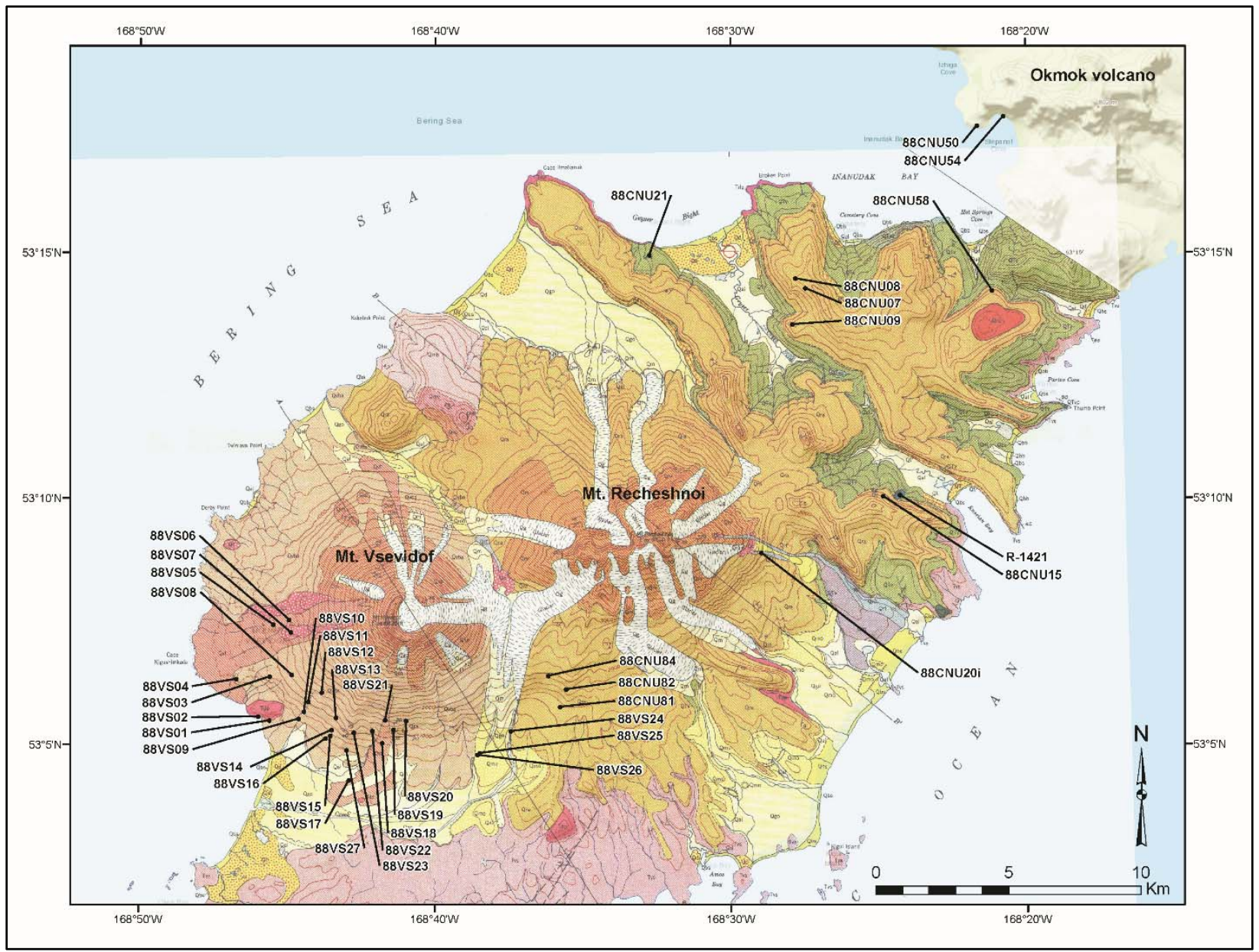

Figure 3. Map of central Umnak Island showing locations of samples with analyses in this report. The geologic base is Plate 40 from Byers (1959). 

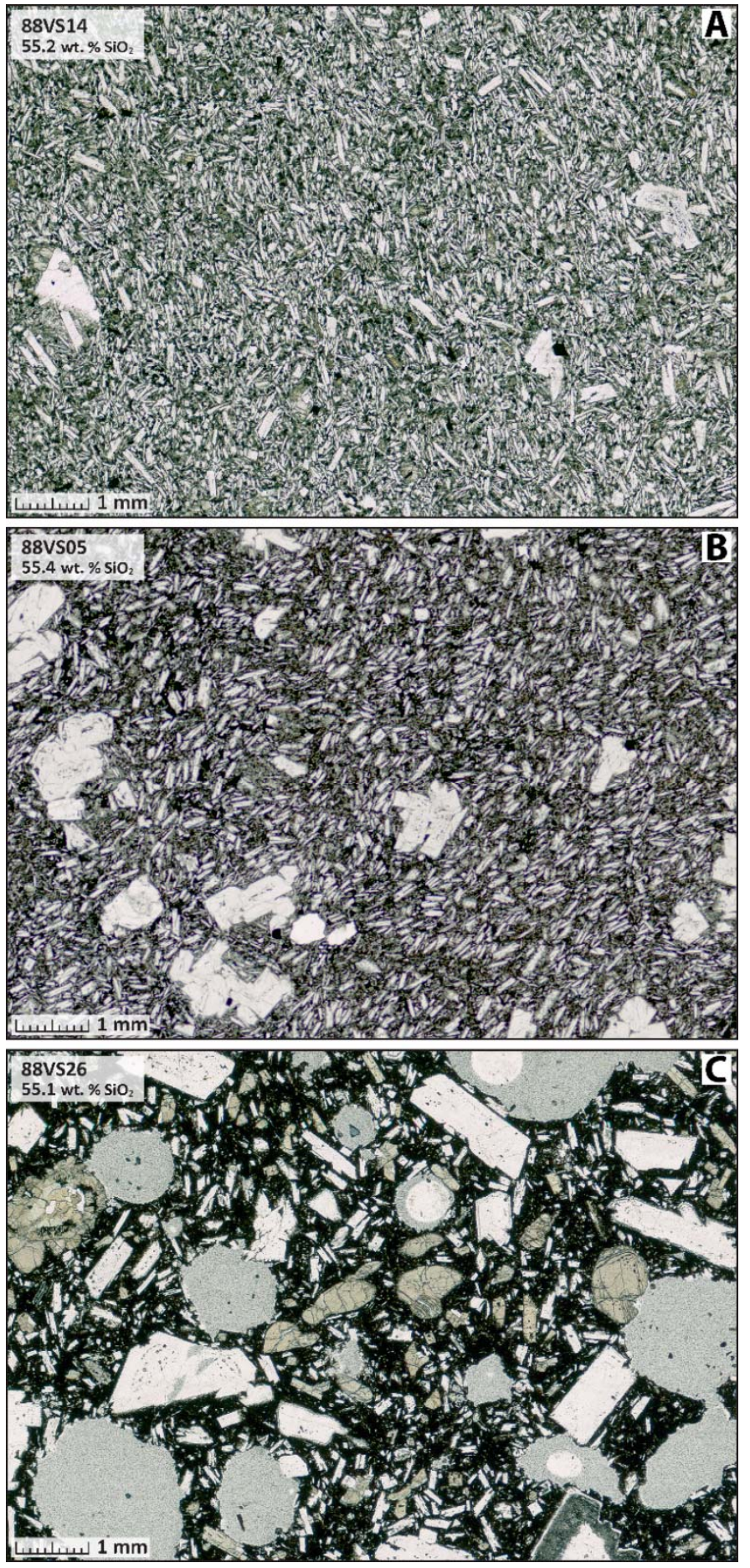

Figure 4. Photomicrographs of selected Vsevidof samples. All are in plane-polarized light and each is $7 \times 10 \mathrm{~mm}$. Aphyric lavas (A) are the most common, sparsely phyric lavas (B) are much less common, and porphyritic lavas (C) are rare. on the geologic map of Byers (1959, plate 40) and are show on figure 3. The map was subsequently georectified to the current USGS 1:250,000 Umnak topographic sheet and sample locations extracted.

The Vsevidof samples and previously unanalyzed samples from the Geyser Bight study were analyzed by the GeoAnalytical Laboratory at Washington State University in August, 1990.

The Vsevidof samples comprise sixteen basaltic andesites, nine andesites, and two dacites, all but one of which are medium-K and tholeiitic; the lowest- $\mathrm{SiO}_{2}$ basaltic andesite straddles the tholeiiticcalcalkaline dividing line. The lavas are typically aphanitic to sparsely phyric with microphenocrysts of plagioclase, olivine or olivine plus clinopyroxene in basaltic andesites, clinopyroxene or clinopyroxene plus orthopyroxene in andesites, and clinopyroxene plus orthopyroxene in dacites. Petrographic descriptions for each sample are in the attached geochemical and sample description digital data file. Photomicrographs of three representative samples are shown in figure 4 . In most samples the plagioclase phenocrysts and microphenocrysts are clear throughout, without spongy zones indicative of prior disequilibrium. One sample (88VS26) is coarsely porphyritic, and one sample (88VS11) contains plagioclase phenocrysts with extensive spongy zones. Groundmasses are typically microcrystalline to hypocrystalline, with plagioclase laths, intersertal ferromagnesian minerals and only small amounts of interstitial glass. 
Data for five Recheshnoi basalt, three basaltic andesite, three andesite, and two high-silica rhyolite lavas are included. These samples were not analyzed as part of the Geyser Bight study. The mafic lavas straddle the tholeiitic-calcalkaline dividing line and the andesites are strongly calcalkaline, similar to other Recheshnoi compositions from the literature. Of note are XRF and ICP/MS analyses of two high-silica rhyolite samples. These are from the $2 \mathrm{~km}$ long east-west trending chain of small domes on the southern wall of Russian Bay valley. These domes are likely the surface expression of a single dike emplaced $135 \mathrm{ka}$ ago (Nye and others, 1992; Motyka and others, 1993), which is the only known high-silica rhyolite locality in the modern Aleutian Arc outside Katmai.

\section{OKMOK}

Reanalyses of thirteen samples, including three primitive basalts (id-01w, id-18w, and id-25w) from Okmok (Nye, 1983; Nye and Reid, 1986) were obtained in order to provide complete ICP/MS trace element data. Analyses were made in 1997.

\section{AKUTAN}

AVO undertook a geologic mapping program at Akutan in 1996. Analyses included here are from samples collected by Pete Stelling as part of that mapping effort that were not included in the final published map (Richter and other, 1998). They include six tholeiitic and one atypically calcalkaline basaltic andesite, five tholeiitic andesites, one cumulate gabbroic xenolith, and one glassy low-silica, high-potassium rhyolite, all of which are broadly typical of published Akutan analyses.

\section{WESTDAHL}

AVO geologic mapping efforts at Westdahl began in 1998 and were led by Richard Moore, USGS. For that project his samples were analyzed by XRF at the Denver USGS laboratory. When he retired, Moore sent fifty-eight of his samples to Chris Nye so they could be analyzed for traceelements by ICP/MS and added to the internally consistent AVO data set. Those analyses, made in late 2013, are included here. Locations of samples were not given by Moore, so latitude and longitude values are not given in the attached digital data file. This report also includes seventeen samples collected by Pete Stelling in 1998 during the AVO mapping work, and analyzed the same year.

Combined, there are analyses of thirty-seven basalts, twenty-nine basaltic andesites, six andesites and two dacites. Westdahl is among the most tholeiitic volcanoes in the arc in terms of displacement from the tholeiitic-calcalkaline dividing line on a plot of FeOt/MgO vs. $\mathrm{SiO}_{2}$. $\mathrm{Basaltic}$ andesites, andesites, and dacites are aphyric to sparsely phyric and form a tight linear array on a plot of $\mathrm{Ca} \#$ (molar $\mathrm{Ca}(\mathrm{Ca}+\mathrm{Na})$ ) vs. $\mathrm{SiO}_{2}$. Aphyric basalts are collinear with the more silicic lavas. About sixty percent of the basalts are coarsely porphyritic, and their plagioclase crystals typically have extensive spongy zones suggesting disequilibrium. Porphyritic basalts have higher Ca\#, 
falling above the array formed by aphyric lavas. The higher Ca\# of porphyritic basalts may be due to entrainment of antecrysts.

\section{FROSTY}

Thirty samples from Frosty were collected by Nye, Mangan, and Miller in 2003 and 2005. There are two basalts, two basaltic andesites, and twenty-six andesites. Basaltic andesites and andesites are calcalkaline, but near the tholeiitic-calcalkaline dividing line on a plot of FeOt/MgO vs. $\mathrm{SiO}_{2}$. The most recent major activity was emplacement of a summit dome and surrounding block and ash flows on the proximal and distal flanks. Field observations indicate this activity was postglacial, and likely of early Holocene age. Ten of the samples are from juvenile blocks in the block and ash flows and are 60-62 wt. \% $\mathrm{SiO}_{2}$ amphibole andesite.

\section{DANA}

Dana is an isolated cone $6 \mathrm{~km}$ in diameter and about $1 \mathrm{~km}$ high with a summit elevation of 1,354 $\mathrm{m}$. It lies along the volcanic front on the lower Alaska Peninsula $45 \mathrm{~km}$ northeast of Pavlof Sister and $80 \mathrm{~km}$ southwest of the southwestern-most Stepovak Bay volcano. There is a $2 \mathrm{~km}$ summit crater, and the upper flanks of the cone are blanketed with pyroclastic deposits. Mangan collected three samples from a single location $5 \mathrm{~km}$ south of the crater-all from juvenile blocks from the blanketing pyroclastic flow. They have $62-65 \mathrm{wt}$. $\% \mathrm{SiO}_{2}$, and are unusual in having dramatically higher $\mathrm{La} / \mathrm{Yb}$ than neighboring volcanoes, as well as other volcanoes in the arc save those behind the volcanic front or at the extreme eastern and western ends of the arc.

\section{UKINREK MAARS}

Primitive basalt erupted through non-volcanic country-rock in 1977 forming Ukinrek Maars. The maars are $12 \mathrm{~km}$ northwest of Peulik volcano, and somewhat behind the main volcanic arc. Arguably primary basalt such as that erupted at Ukinrek is quite rare in the Aleutian Arc. Eleven samples were collected by McConnell in 1993 and 1994, and those analyses are included here. Ukinrek basalt contains only phenocrysts of olivine ( $<10 \%$ vol. $\%, 0.5-1 \mathrm{~mm}$ dia.), which are euhedral with moderately well-developed quench terminations and contain an unusually high proportion of translucent brown spinel octahedral (fig. 5). Plagioclase and clinopyroxene are present only as groundmass microlites.

\section{KAGUYAK AND FOURPEAKED}

In the course of focused fieldwork at Douglas (see below) brief stops were made at Kaguyak and Fourpeaked, and a single sample was collected and analyzed from each. The Geochronology Laboratory at the University of Alaska Fairbanks determined a ${ }^{40} \mathrm{Ar} /{ }^{39} \mathrm{Ar}$ age of $45 \pm 34 \mathrm{ka}$ for the Fourpeaked sample (Sample, 91CNF01, table 2).

\section{DOUGLAS}

Douglas is in the eastern Aleutian Arc, at the point where the northeasterly trend of the Katmai group changes abruptly northward to the north northeasterly trend of the Cook Inlet volcanoes. 
Douglas is largely ice-covered, making knowledge of the exact nature of the volcano uncertain. Volcanic outcrops surrounded by ice and beyond glacier and ice margins were mapped and sampled in 1991 and are show on figure 6. The observed geology and interpretation of subglacial morphology suggest that Douglas is mainly a small cone about six kilometers in diameter and 900 $\mathrm{m}$ tall with a base elevation of about 1,250 $\mathrm{m}$ (4,100 feet), and that lavas flowed beyond this cone into adjacent lowlands up to $13 \mathrm{~km}$ distant. These distal flows cap preexisting sloping sedimentary and plutonic country-rock surfaces. Subvolcanic basement is exposed as high as 4,500 feet

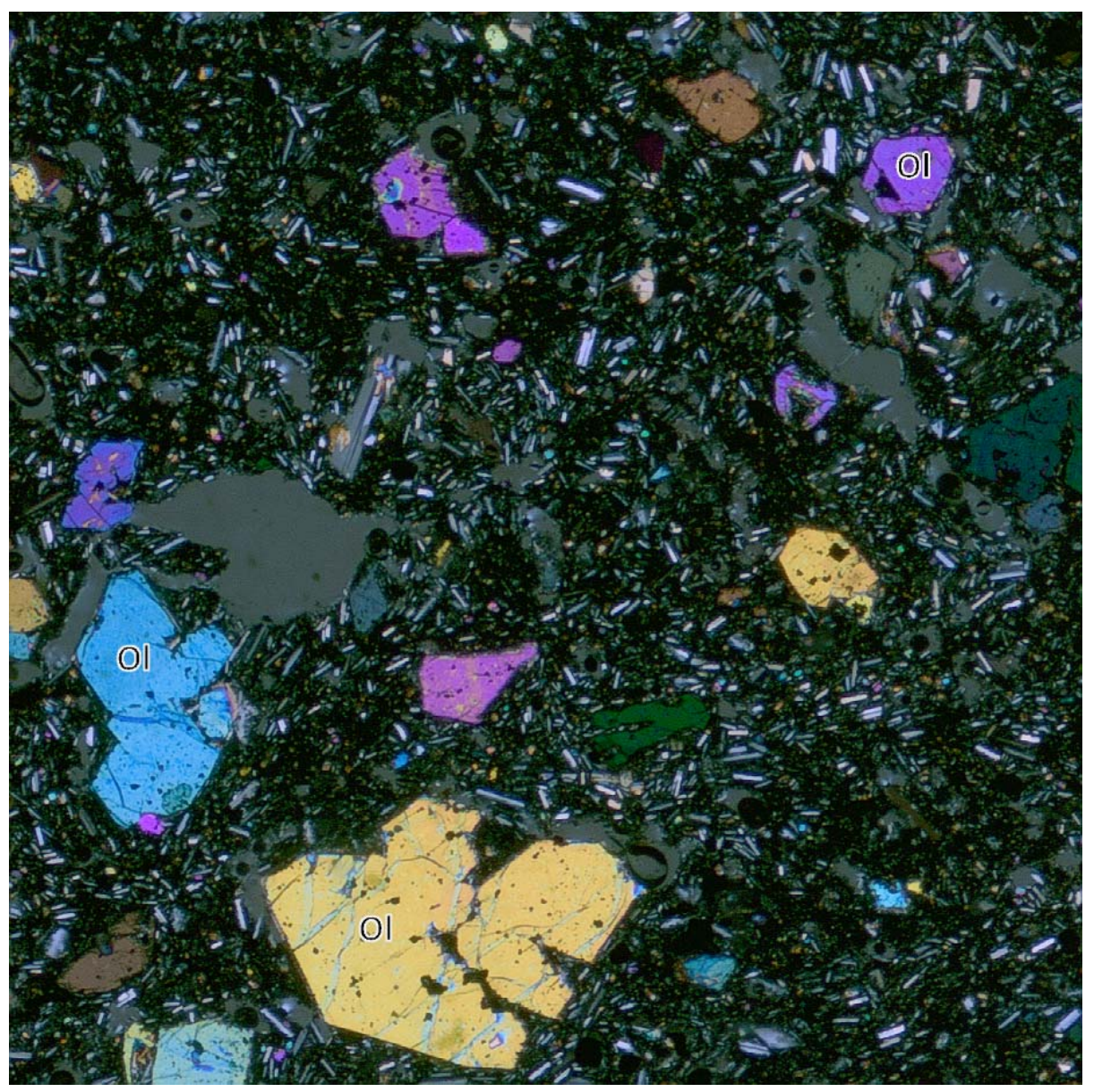

Figure 5. Photomicrograph of Ukinrek Maars basalt UK11 with partially crossed polarizers. Note large euhedral olivine phenocrysts $(\mathrm{OI})$ and lack of plagioclase or pyroxene phenocrysts. Most of the small dark inclusions in olivine crystals are euhedral translucent brown chromite. Irregular uniformly gray patches are voids. Image is $5 \times 5 \mathrm{~mm}$.

elevation immediately southwest of the main cone, and there are several other outcrops of basement at elevations up to 4,500 feet surrounding the main cone. Additional bedrock outcrops appear between lava flows at a variety of elevations around the main cone (fig. 6).

${ }^{40} \mathrm{Ar} /{ }^{39} \mathrm{Ar}$ ages of lavas from the east flank are $452 \pm 45$ and $584 \pm 50 \mathrm{ka}$. An age of $149 \pm 27 \mathrm{ka}$ was determined for a lava on the distal north flank, and ages of $71 \pm 22$ and $78 \pm 56$ ka were measured on lavas from the northwest flank (table 2).

Douglas lavas are dominantly andesite, with subordinate dacite and a few basaltic andesite magmatic inclusions. All are highly calcalkaline-at the limit of the Aleutian Arc array in $\mathrm{FeOt} / \mathrm{MgO}$ vs. $\mathrm{SiO}_{2}$ space. They share dramatically low concentrations of $\mathrm{Nb}$ with neighboring 
Augustine and Kaguyak, but have $\mathrm{K}_{2} \mathrm{O}$ about $0.5 \mathrm{wt} \%$ higher than either. Douglas andesites have higher concentrations of $\mathrm{MgO}, \mathrm{Cr}$, and $\mathrm{Ni}$ than andesites from most other Aleutian Arc centers. A subset of the andesites are especially unusual in that they have 4-6.6 wt. \% MgO, 40-90 ppm Ni, and 90-260 ppm Cr. Samples in this subset typically have large euhedral phenocrysts of chromite- 


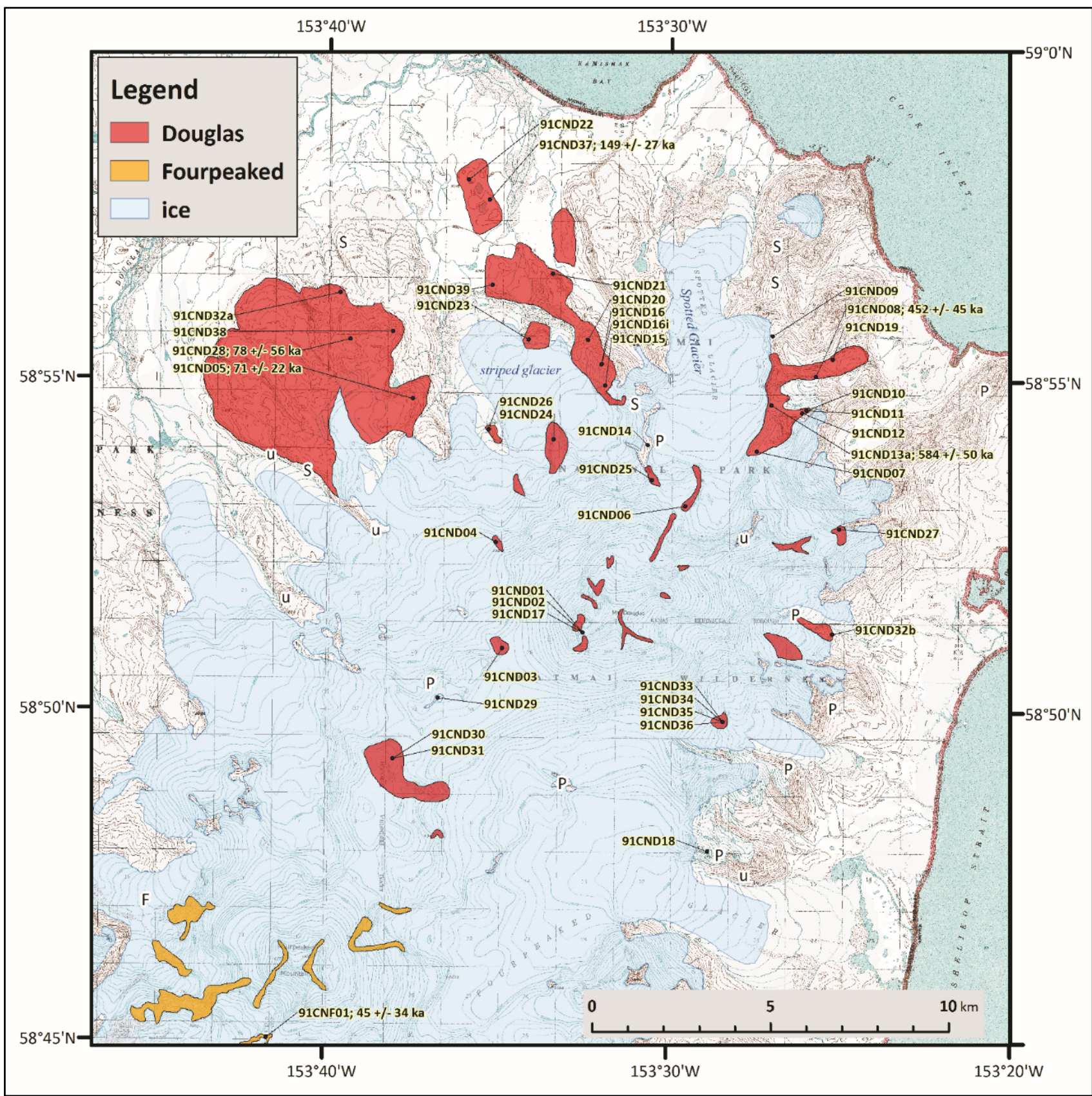

Figure 6. Map showing locations of Douglas and Fourpeaked samples with data included in this report. Outcrop areas of Douglas lavas are in red, and Fourpeaked lavas are in orange. Ice cover in 1991 is shown - note retreat of glacier termini since the original base topographic map was made in 1951. Spot identification of bedrock lithology is shown as single letters ( $P$, plutonic; $S$, sedimentary; $u$, undetermined). Note that non-volcanic basement occurs at elevations as high as 4,500 feet, indicating that Douglas is a moderate-sized cone perched on pre-existing country rock.

bearing olivine in addition to plagioclase and clinopyroxene. Douglas lavas are all porphyritic, with plagioclase followed by clino and orthopyroxene as dominant phases. In most samples plagioclase phenocrysts have less well developed sieve textures than are typical in Aleutian Arc magmas, although a few samples are dominated by sieved plagioclase. Petrographic descriptions for each sample are in the attached digital data file. 
Table 2. Eight ${ }^{40} \mathrm{Ar} /{ }^{39} \mathrm{Ar}$ ages from Douglas volcano (samples that include "CND" in sample name), and one age from Fourpeaked volcano (sample 91CNF01). Age analyses from the University of Alaska Fairbanks Geochronology Laboratory.

\begin{tabular}{|c|c|c|c|c|c|c|}
\hline Sample & RUN & $\begin{array}{l}\text { Integrated } \\
\text { Age (ka) }\end{array}$ & $\begin{array}{l}\text { Plateau } \\
\text { Age (ka) }\end{array}$ & Plateau information & $\begin{array}{l}\text { Isochron } \\
\text { Age (ka) }\end{array}$ & Isochron information \\
\hline 91CND01 & WR & $-18 \pm 26$ & $-25 \pm 29$ & $\begin{array}{l}77 \%{ }^{39} \mathrm{Ar} \text { release } \\
\mathrm{n}=6, \mathrm{MSWD}=0.4\end{array}$ & $-10 \pm 49$ & $\begin{array}{l}{ }^{40} \mathrm{Ar} /{ }^{36} \mathrm{Ar}_{\mathrm{i}}=291 \pm 7 \\
\mathrm{n}=7, \mathrm{MSWD}=0.6\end{array}$ \\
\hline 91CND17 & $\begin{array}{l}\text { WR\#1 } \\
\text { WR\#2 } \\
2 \text { run }\end{array}$ & $\begin{array}{c}223 \pm 72 \\
-307 \pm 117 \\
\text { ghted mean }\end{array}$ & $\begin{array}{l}217 \pm 54 \\
109 \pm 77 \\
181 \pm 51\end{array}$ & $\begin{array}{l}96 \%{ }^{39} \mathrm{Ar} \text { release } \\
\mathrm{n}=1, \mathrm{MSWD}=\mathrm{N} / \mathrm{A} \\
55 \%{ }^{39} \mathrm{Ar} \text { release } \\
\mathrm{n}=1, \mathrm{MSWD}=\mathrm{N} / \mathrm{A} \\
\mathrm{MSWD}=\mathbf{0 . 8}\end{array}$ & $\begin{array}{l}\text { none } \\
\text { none }\end{array}$ & $\begin{array}{l}2 \text { step run } \\
\text { Bad run for plateau } \\
\text { analysis. }\end{array}$ \\
\hline 91CND05 & $\begin{array}{l}\text { WR\#1 } \\
\text { WR\#2 } \\
2 \text { run } \\
\end{array}$ & $\begin{array}{r}167 \pm 84 \\
83 \pm 31 \\
\text { ghted mean } \\
\end{array}$ & $\begin{array}{l}128 \pm 68 \\
64 \pm 23 \\
71 \pm 22 \\
\end{array}$ & $\begin{array}{l}92 \%{ }^{39} \mathrm{Ar} \text { release } \\
\mathrm{n}=4, \mathrm{MSWD}=0.3 \\
83 \%{ }^{39} \mathrm{Ar} \text { release } \\
\mathrm{n}=3, \mathrm{MSWD}=0.6 \\
\mathrm{MSWD}=\mathbf{0 . 8}\end{array}$ & $\begin{array}{l}112 \pm 93 \\
38 \pm 24\end{array}$ & $\begin{array}{l}{ }^{40} \mathrm{Ar} /{ }^{36} \mathrm{Ar}_{i}=302 \pm 34 \\
\mathrm{n}=6, \mathrm{MSWD}=0.2 \\
{ }^{40} \mathrm{Ar} /{ }^{36} \mathrm{Ar}_{i}=302 \pm 6 \\
\mathrm{n}=6, \mathrm{MSWD}=0.1\end{array}$ \\
\hline 91CND28 & $\begin{array}{l}\text { WR\#1 } \\
\text { WR\#2 } \\
2 \text { run } \\
\end{array}$ & $\begin{array}{r}331 \pm 91 \\
84 \pm 35 \\
\text { ghted mean } \\
\end{array}$ & $\begin{array}{l}225 \pm 81 \\
57 \pm 31 \\
78 \pm 56 \\
\end{array}$ & $\begin{array}{l}74 \%{ }^{39} \mathrm{Ar} \text { release } \\
\mathrm{n}=3, \mathrm{MSWD}=0.2 \\
87 \%{ }^{39} \mathrm{Ar} \text { release } \\
\mathrm{n}=5, \mathrm{MSWD}=0.4 \\
\mathrm{MSWD}=\mathbf{3 . 8}\end{array}$ & $\begin{array}{c}185 \pm 148 \\
67 \pm 48\end{array}$ & $\begin{array}{l}{ }^{40} \mathrm{Ar} /{ }^{36} \mathrm{Ar}_{i}=317 \pm 44 \\
\mathrm{n}=7, \mathrm{MSWD}=1.1 \\
{ }^{40} \mathrm{Ar} /{ }^{36} \mathrm{Ar}_{i}=296 \pm 10 \\
\mathrm{n}=6, \mathrm{MSWD}=0.4\end{array}$ \\
\hline 91CND20 & WR & $140 \pm 95$ & $42 \pm 85$ & $\begin{array}{l}84 \%{ }^{39} \mathrm{Ar} \text { release } \\
\mathrm{n}=4, \mathrm{MSWD}=0.2\end{array}$ & $53 \pm 106$ & $\begin{array}{l}{ }^{40} \mathrm{Ar} /{ }^{36} \mathrm{Ar}_{\mathrm{i}}=304 \pm 25 \\
\mathrm{n}=7, \mathrm{MSWD}=0.6\end{array}$ \\
\hline 91CND37 & $\begin{array}{r}\text { WR\#1 } \\
\text { WR\#2 } \\
2 \text { run } \\
\end{array}$ & $\begin{array}{r}238 \pm 70 \\
277 \pm 39 \\
\text { ghted mean } \\
\end{array}$ & $\begin{array}{l}172 \pm 61 \\
143 \pm 30 \\
149 \pm 27 \\
\end{array}$ & $\begin{array}{l}88 \%{ }^{39} \mathrm{Ar} \text { release } \\
\mathrm{n}=4, \mathrm{MSWD}=0.01 \\
77 \%{ }^{39} \mathrm{Ar} \text { release } \\
\mathrm{n}=3, \mathrm{MSWD}=0.3 \\
\mathrm{MSWD}=\mathbf{0 . 2}\end{array}$ & $\begin{array}{l}153 \pm 68 \\
114 \pm 33\end{array}$ & $\begin{array}{l}{ }^{40} \mathrm{Ar} /{ }^{36} \mathrm{Ar}_{i}=320 \pm 27 \\
\mathrm{n}=7, \mathrm{MSWD}=0.6 \\
{ }^{40} \mathrm{Ar} /{ }^{36} \mathrm{Ar}_{i}=316 \pm 6 \\
\mathrm{n}=8, \mathrm{MSWD}=0.4\end{array}$ \\
\hline 91CND08 & WR & $499 \pm 60$ & $452 \pm 45$ & $\begin{array}{l}91 \%{ }^{39} \mathrm{Ar} \text { release } \\
\mathrm{n}=3, \mathrm{MSWD}=1.1\end{array}$ & $392 \pm 47$ & $\begin{array}{l}{ }^{40} \mathrm{Ar} /{ }^{36} \mathrm{Ar}_{\mathrm{i}}=344 \pm 21 \\
\mathrm{n}=7, \mathrm{MSWD}=0.4\end{array}$ \\
\hline 91CND13A & WR & $584 \pm 50$ & $584 \pm 50$ & $\begin{array}{l}100 \%{ }^{39} \mathrm{Ar} \text { release } \\
\mathrm{n}=7, \mathrm{MSWD}=0.7\end{array}$ & $557 \pm 76$ & $\begin{array}{l}{ }^{40} \mathrm{Ar} /{ }^{36} \mathrm{Ar}_{\mathrm{i}}=297 \pm 12 \\
\mathrm{n}=7 \mathrm{MSWD}=0.8\end{array}$ \\
\hline 91CNF01 & $\begin{array}{l}\text { WR\#2 } \\
2 \text { run }\end{array}$ & $\begin{array}{c}-61 \pm 114 \\
-43 \pm 53 \\
\text { ghted mean }\end{array}$ & $\begin{array}{l}32 \pm 88 \\
47 \pm 37 \\
45 \pm 34\end{array}$ & $\begin{array}{l}86 \%{ }^{39} \mathrm{Ar} \text { release } \\
\mathrm{n}=3 \mathrm{MSWD}=1.1 \\
87 \%{ }^{39} \mathrm{Ar} \text { release } \\
\mathrm{n}=3, \mathrm{MSWD}=2.3 \\
\mathrm{MSWD}=\mathbf{0 . 0 2}\end{array}$ & $\begin{array}{l}87 \pm 179 \\
23 \pm 53\end{array}$ & $\begin{array}{l}{ }^{40} \mathrm{Ar} /{ }^{36} \mathrm{Ar}_{\mathrm{i}}=283 \pm 9 \\
\mathrm{n}=5, \mathrm{MSWD}=0.2 \\
{ }^{40} \mathrm{Ar} /{ }^{66} \mathrm{Ar}_{\mathrm{i}}=296 \pm 2 \\
\mathrm{n}=8, \mathrm{MSWD}=2.3\end{array}$ \\
\hline
\end{tabular}

All samples run with Bern-4B biotite standard $(17.25 \mathrm{Ma})$. Best interpreted ages for each sample are shown in Bold. With the exception of 91CND37 run 2, all isochrons were within 2-sigma of atmospheric, therefore we use the plateau age for each sample as the interpreted age. In cases where two runs were done on the same sample, the plateau ages are averaged and a weighted mean age is reported. For sample 91CND17, both runs had poor heating schedules. Weighted average age is from single fractions for each run and no isochron ages could be calculated. WR: Whole rock, $\mathrm{n}$ : number of fractions used in plateau or isochron calculation, MSWD: Mean Square Weighted Deviates.

If all 4 runs from the NW Flank samples 91CND05 and 91CND28 are averaged, the weighted mean age is $73 \pm 22$ ka. If all 3 runs from the Striped Glacier samples $91 \mathrm{CND} 20$ and 91CND37 are averaged, the weighted mean age is $139 \pm 26 \mathrm{ka}$. If both runs from the stratigraphically similar samples 91CND08 and 91CND13A are averaged, the weighted mean age is $511 \pm 66 \mathrm{ka}$, although the age difference between the two samples is significant, so averaging may not be warranted. 


\section{AUGUSTINE}

In 1990 there were seventy published analyses of Augustine lavas and pyroclasts. All concentrations were measured by XRF. Half of these analyses were for major elements only, a quarter included $\mathrm{Rb}, \mathrm{Sr}, \mathrm{Y}$, and $\mathrm{Zr}$ concentrations, and a quarter included concentrations of about 10 more elements. There were no high-precision, complete, trace-element data. AVO acquired high-precision XRF and ICP/MS major and trace-element analyses for a representative suite of twenty-five pyroclasts including twenty-two samples from six separate eruptive events between about 0.35 and $2 \mathrm{ka}$ and three samples from earliest Holocene or latest Pleistocene eruptions in order to determine if there had been temporal changes in the compositions of erupted magmas. Those analyses are included in this report. No statistically significant compositional changes were found between units erupted since $2 \mathrm{ka}$; all consist of andesite and dacite, and the spread of compositions in single eruptions is similar to the total combined spread. The three older samples are rhyolite, distinctly more silicic than the other samples. Augustine magmas are among the most calcalkaline in the arc, and have notably low concentrations of potassium and other incompatible elements-among the lowest of well-analyzed Aleutian Arc volcanoes.

\section{ILIAMNA}

On July 23, 1991 samples spanning a range of lithologies were collected from a single stop at an elevation of 2,400 feet on the Red Glacier. The location is at a fork in the glacier, and the rocks sampled could have come from either the main cone or North Twin. On July 28, 1991 samples spanning a range of lithologies were collected from a single stop at an elevation of 2,200 feet on the Umbrella Glacier. A total of twenty-five samples were collected and analyzed, and those data are included in this report. At both sites blocks of homogeneous lava containing rounded magmatic inclusions were common. Where both the host lava and a magmatic inclusion were collected from a single block the sample number for the inclusion has a trailing "i" (e.g. 91CNI02, host; and 92CNI02i, inclusion).

Fourteen of the eighteen lava samples are texturally monotonous porphyritic two-pyroxene andesites with 59.5-62.6 wt. \% $\mathrm{SiO}_{2}$ (fig. 7). Most of the plagioclase phenocryst in the samples are not extensively sieved, and neither olivine nor amphibole are present. Three of the eighteen lava samples are compositionally and texturally self-similar, and distinct from the typical samples in having $\mathrm{SiO}_{2}$ concentrations about 4 wt. \% lower; having extensively sieved plagioclase phenocrysts; and having deep reddish brown glass interstitial to groundmass microlites instead of the typical clear glass. The most mafic lava sample (91CNI09) has $56.4 \mathrm{wt} . \% \mathrm{SiO}_{2}$ and is the only lava sample to have olivine phenocrysts.

Six of the seven magmatic inclusions are basaltic andesites (52.2-56.1 wt. \% $\mathrm{SiO}_{2}$ ). All are sparsely porphyritic with groundmasses of interlocking plagioclase laths trapping pyroxene, opaque oxides, and small amounts of clear glass (fig. 7). The magmatic inclusions have 2.5-10 wt. \% lower $\mathrm{SiO}_{2}$ concentrations than their host magmas, and the compositional range of these magmatic inclusions does not overlap the range of host lavas. The seventh magmatic inclusion has 

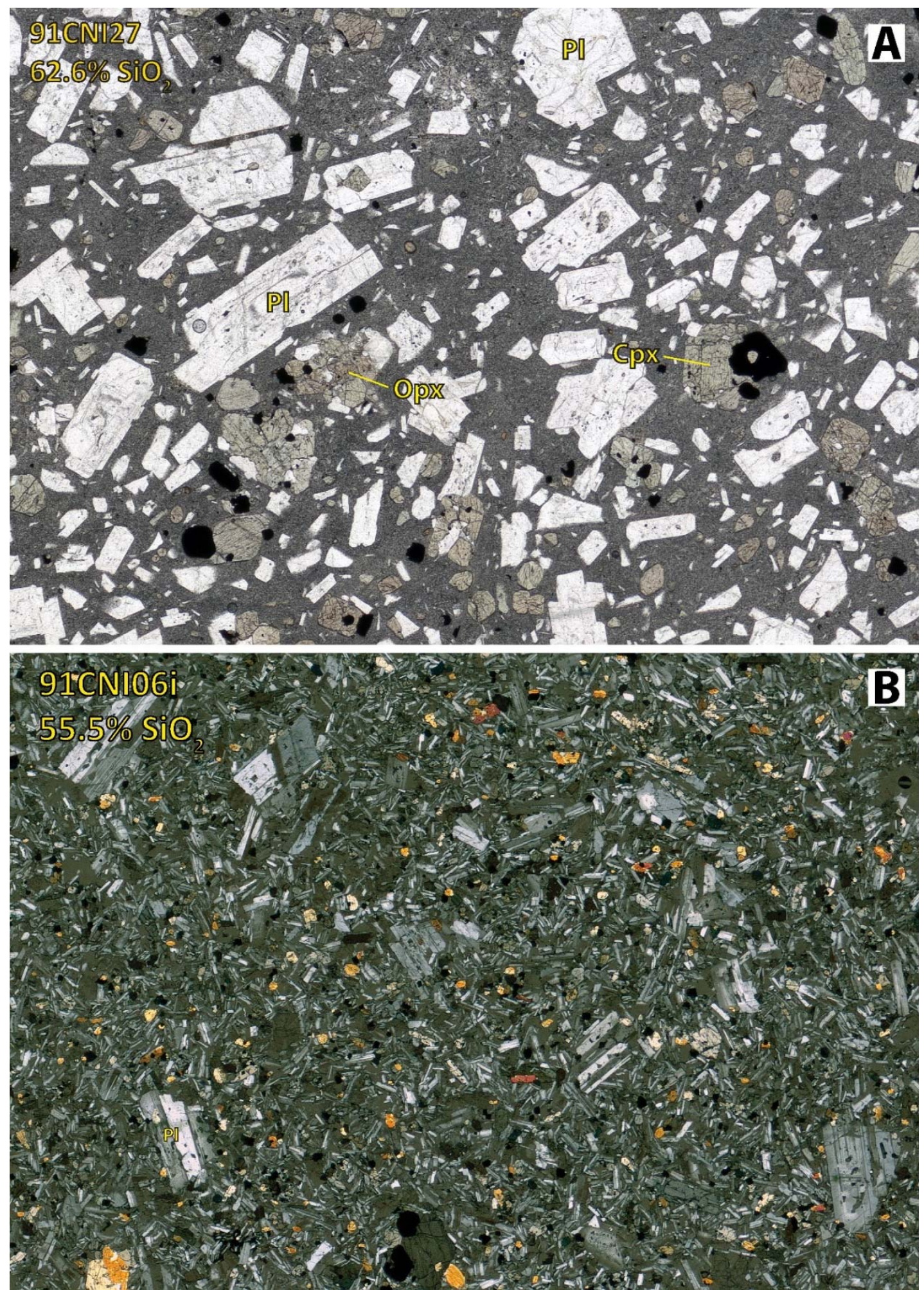

Figure 7. (A) Photomicrograph of typical porphyritic two-pyroxene andesite from lliamna in plane-polarized light. (B) Representative magmatic inclusion with partially crossed polarizers. Uniformly gray areas between microlites are voids. Each image is $7 \times 10 \mathrm{~mm}$. Representative grains of plagioclase (PI), clinopyroxene (Cpx), and orthopyroxene (Opx) are labeled. Whole-rock wt. $\% \mathrm{SiO}_{2}$ for each sample is given below the sample number. 
a $\mathrm{SiO}_{2}$ concentration that is $2.5 \mathrm{wt}$. \% higher than its host, and is the only sample with a microlitefree glassy groundmass.

The lavas and magmatic inclusions together have a fairly linear calcalkaline trend that is low-K, but not as low as Augustine or Kaguyak.

\section{REDOUBT}

This report includes seventy-four analyses of samples from Redoubt collected in or before 1990 as follows:

- Nineteen analyses of samples of juvenile ejecta and one sample of included granitic country rock from 1989-90 eruption deposits. Thirty-eight representative analyses of 1989-90 eruption deposits spanning the compositional range of each eruption episode are in Nye and others (1994); the nineteen samples in this report are largely redundant.

- Twenty-one analyses of samples of coarse tephra from undated Holocene tephra sections. Begét and Nye (1994) report data from similar samples from dated tephra sections.

- Eleven analyses of miscellaneous Holocene and latest Pleistocene lavas, and two analyses of basaltic andesite and andesite magmatic inclusions in those lavas.

- Two analyses of granitic country rock included in lavas.

- Twenty analyses of dense lava samples from the AVO sample archive. All are conebuilding lava samples collected by S. Swanson and J. Kienle in 1978 and 1980.

Ongoing thorough geologic mapping and tephrochronology studies by AVO will dramatically overshadow the data reported here.

\section{SPURR}

The State of Alaska Division of Geological \& Geophysical Surveys (DGGS) and the University of Alaska Fairbanks Geophysical Institute (UAF/GI) conducted a multidisciplinary geological and geophysical geothermal resource investigation of Spurr in 1985. As part of that study Nye collected a stratigraphically comprehensive set of sixty-five volcanic samples, and whole-rock major element and limited trace element concentrations in these samples were measured by XRF at the (now closed) DGGS analytical laboratory. In 1986, five hundred eighty six analyses of mineral phenocrysts were made by Nye using the JEOL JXA-733 microprobe at Southern Methodist University. The whole-rock and modal data, and interpretation of those data and the mineral data, are in Nye and Turner (1990). The mineral data themselves are in Nye (1987).

The samples collected in 1985 were analyzed by XRF and ICP/MS in 1992 in order to obtain complete trace-element data and to establish geochemical context for magma erupted in 1992. Those data are included in this report.

Spurr magmas are porphyritic calcalkaline medium-K basaltic andesite and andesite with variable and sometimes quite high $\mathrm{MgO}, \mathrm{Ni}$, and $\mathrm{Cr}$. They average $35 \pm 8$ vol. \% phenocrysts 
dominated by plagioclase; all samples contain clinopyroxene, with typical modal abundances being about 4 vol. \%, and all but two contain subequal amounts of orthopyroxene. Most mafic samples contain trace to several percent olivine. Amphibole was not seen in any ancestral Mount Spurr samples; several of the samples from younger units have trace to minor amounts of amphibole.

\section{BUZZARD CREEK AND PRINDLE}

Buzzard Creek maars consists of two 3 ka vents (Wood and Kienle, 1990), $\sim 150 \mathrm{~m}$ and $\sim 50 \mathrm{~m}$ in diameter, on the north flank of the Alaska Range. Each consists of a low-relief tephra ring surrounding a small lake. They lie directly above the Benioff Zone associated with Pacific Plate subduction; are $15 \mathrm{~km}$ northeast of the Pleistocene Jumbo Dome; and $360 \mathrm{~km}$ northeast along the strike of the Benioff Zone from Hayes volcano, the closest Holocene Aleutian Arc volcano; no Quaternary volcanism has been identified between Jumbo Dome and Buzzard Creek maars and Hayes. Buzzard Creek is also $560 \mathrm{~km}$ from the Aleutian Trench, much of that distance characterized by flat-slab subduction. The maars are about $65 \mathrm{~km}$ north of the Denali Fault, in an area of transtensional right lateral "bookshelf" faulting between the Denali and Tintina faults. It is likely that the transtensional stress allowed the unimpeded rise of Buzzard Creek basalt through the crust.

Prindle is a small cinder cone in the Yukon-Tanana uplands, $335 \mathrm{~km}$ east-northeast of the Buzzard Creek maars. It is, by a small margin, the closest Quaternary vent to Buzzard Creek. Historically, its relative proximity invited comparison to the Buzzard Creek maars.

The lack of robust volcanism along the easternmost $360 \mathrm{~km}$ of the Pacific-North America subduction system was puzzling. One possibility was that volcanism stopped north-east of the Cook Inlet volcanoes because magmatism stopped due in some way to the flat-slab subduction (i.e. there was a magmatic gap). In that case it was supposed that Buzzard Creek maars might be more akin to Prindle volcano, and be part of the belt of non-arc volcanoes of British Columbia, the Yukon, and interior Alaska. Alternatively, Buzzard Creek basalt might be an arc basalt, as one might expect since it sits above the Benioff Zone, and the gap between it and the Cook Inlet volcanoes might result from failure to erupt magmas, rather than failure to produce them (i.e. it might be a volcanic gap, but not a magmatic gap). The trace element data necessary to test these two hypotheses did not exist, so Buzzard Creek was sampled in 1998, and the samples analyzed in 1999 and 2001, along with a sample from Prindle volcano which had been previously collected by Bob Forbes.

Buzzard Creek basalt has low concentrations of HFSE with respect to LILE which are the hallmark of arc volcanism, and are distinctly different than Prindle. For instance $\mathrm{Nb} / \mathrm{Rb}$ is 0.21 at Buzzard Creek, comparable to $0.19 \pm 0.08$ at Spurr and $0.18 \pm 0.12$ for the entire Aleutian Arc and distinct from 5.1 at Prindle. Buzzard Creek also has a relatively flat REE pattern $(\mathrm{La} / \mathrm{Yb}=7.8)$, similar to Spurr (7.2 \pm 1.3$)$ and distinct from Prindle (33.2). 
Buzzard Creek magma is also one of the few arguably primary magmas to have erupted anywhere in the Aleutian Arc in Holocene time, with 9.9 wt. \% MgO, 183 ppm Ni, and 456 ppm Cr. The basalt has euhedral phenocrysts of chromite-bearing olivine and clinopyroxene, but not plagioclase (fig. 8). Plagioclase is restricted to groundmass microlites. The Buzzard Creek samples also have a few to several percent angular fragments of the bedrock the basalt erupted through, which is polymetamorphic pre-Cambrian schist. An analysis of a block of the schist taken from Buzzard Creek ejecta is also included in this report.
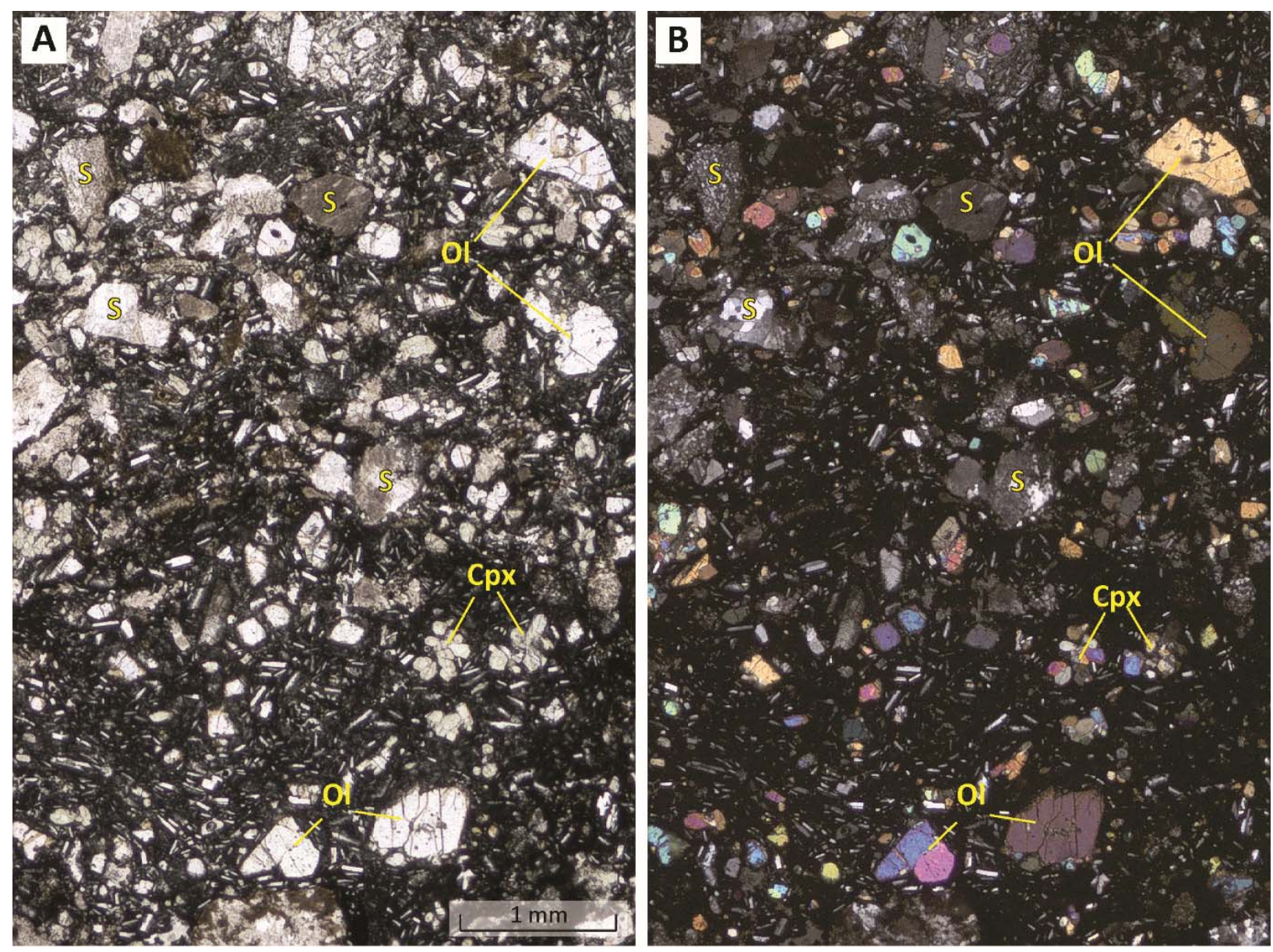

Figure 8. Photomicrograph of Buzzard Creek maars basalt in plane-polarized light (A) and with partially crossed polarizers (B). Example olivine phenocrysts (Ol) and clinopyroxene microphenocrysts (Cpx) are shown, as are angular inclusions of the schist (S) the basalt erupted through. Each image is $5 \times 7 \mathrm{~mm}$.

\section{WRANGELL}

Mount Wrangell is the active member of a $200 \mathrm{~km}$ long chain of massive stratovolcanoes and abundant monogenetic vents in southern Alaska. The Wrangell chain is northwest trending, perpendicular to the trend of the Cook Inlet volcanoes, and appears to result from northerly subduction of the Yakutat Block, or whatever crust previously existed on the leading edge of the block. XRF major and limited trace element data for 101 lava samples from Wrangell are included in Nye (1983). Thirty four of those samples were re-analyzed by XRF and ICP/MS in 2006 in order 
to determine their full trace-element chemistry. The reanalyzed samples have 52.9-62.9 wt. \% $\mathrm{SiO}_{2}$, and are broadly similar to Aleutian Arc samples in their low, diagnostically arc-like, HFSE/LILE (e.g. Nb/Rb of $0.14 \pm 0.05$, comparable to $0.18 \pm 0.12$ for the Aleutian Arc). They are atypical of Aleutian Arc lavas in their high Ni (30-100 ppm in andesites) and also have high concentrations of $\mathrm{MgO}$ and $\mathrm{Cr}$, although those are at the margin of the Aleutian Arc distribution. Wrangell magmas also have higher $\mathrm{La} / \mathrm{Yb}$ than typical Aleutian Arc magmas, but similar to Buzzard Creek, Jumbo Dome, and Hayes in the easternmost arc and Dana and Uliaga in the central arc.

\section{REFERENCES}

Begét, J. E., and Nye, C. J., 1994, Postglacial eruption history of Redoubt volcano, Alaska: in Miller, T. P. and Chouet, B. A., (eds.), The 1989-1990 eruptions of Redoubt Volcano, Alaska, Journal of Volcanology and Geothermal Research, v. 62, n. 1, p. 31-54.

Byers, F. M. Jr., 1959, Geology of Umnak and Bogoslof Islands, Aleutian Islands, Alaska: in Investigations of Alaskan volcanoes, U.S. Geological Survey Bulletin B 1028-L, p. 267-369, 5 sheets, scale 1 at 1:63,360, 1 at 1:96,000, and 1 at 1:300,000.

Cameron, C.E., Snedigar, S.F., and Nye, C.J., 2014, Alaska Volcano Observatory geochemical database: Alaska Division of Geological \& Geophysical Surveys Digital Data Series 8. http://www.avo.alaska.edu/geochem/index.php, http://doi.org/10.14509/29120

Coats, R.R., 1956, Geology of northern Adak Island, Alaska: in Investigations of Alaskan volcanoes, U.S. Geological Survey Bulletin 1028-C, p. 45-67, 1 sheet, scale 1:50,000.

Motyka, R. J., Nye, C. J., Turner, D. L., and Liss, S. A., 1993, The Geyser Bight geothermal area, Umnak Island, Alaska: Geothermics, v. 22, n. 4, p. 301-327.

Nye, C. J., 1983, Petrology and geochemistry of Okmok and Wrangell volcanoes, Alaska: University of California, Santa Cruz Ph.D. dissertation, 208 p.

Nye, C. J., 1987, Stratigraphy, petrology and geochemistry of the Spurr volcanic complex, eastern Aleutian Arc, Alaska: University of Alaska Fairbanks Geophysical Institute Report UAG-R $311,135 \mathrm{p}$.

Nye, C. J., and Reid, M. R., 1986, Geochemistry of primary and least fractionated lavas from Okmok volcano, Central Aleutians: implications for arc magmagenesis: Journal of Geophysical Research, v. 91, n. B10, p. 10,271-10,287.

Nye, C. J., and Turner, D. L., 1990, Petrology, geochemistry, and age of the Spurr volcanic complex, eastern Aleutian Arc: Bulletin of Volcanology, v. 52, n. 3, p. 205-226.

Nye, C. J., Swanson, S. E., Avery, V. F., and Miller, T. P., 1994, Geochemistry of the 1989-1990 eruption of Redoubt Volcano: Part I. Whole-rock major- and trace-element chemistry: in Miller, T. P. and Chouet, B. A., (eds.), The 1989-1990 eruptions of Redoubt Volcano, Alaska, Journal of Volcanology and Geothermal Research, v. 62, n. 1-4, p. 429-452.

Nye, C.J., Motyka, R.J., Turner, D.L., and Liss, S.A., 1992, Geology and geochemistry of the Geyser Bight Geothermal area, Umnak Island, Aleutian Islands, Alaska: Alaska Division of 
Geological \& Geophysical Surveys Report of Investigation 92-1, 85 p., 2 sheets, scale 1:24,000. http://doi.org/10.14509/2480

Nye, C.J., Scott, W.E., Neill, O.K., Waythomas, C.F., Cameron, C.E., and Calvert, A.T., 2017, Geology of Kasatochi volcano, Aleutian Islands, Alaska: Alaska Division of Geological \& Geophysical Surveys Professional Report 123, 127 p., 1 sheet, scale 1:5,000. http://doi.org/10.14509/29718

Richter, D. H., Waythomas, C. F., McGimsey, R. G., and Stelling, P. L., 1998, Geologic map of Akutan Island, Alaska: U.S. Geological Survey Open-File Report OF 98-0135, 22 p., 1 sheet, scale 1:48,000.

Waythomas, C. F., Miller, T. P., and Nye, C. J., 2003, Preliminary geologic map of Great Sitkin Volcano, Alaska: U.S. Geological Survey Open-File Report OF 03-0036, unpaged, 1 sheet, scale $1: 63,360$.

Wood, C. A., and Kienle, Juergen, (eds.), 1990, Volcanoes of North America: United States and Canada: New York, Cambridge University Press, 354 p.

Yogodzinski, G.M., Brown, S.T., Kelemen, P.B., Vervoort, J.D., Portnyagin, Maxim, Sims, K.W.W., Hoernle, Kaj, Jicha, B.R., and Werner, Reinhard, 2015, The role of subducted basalt in the source of island arc magmas: evidence from seafloor lavas of the Western Aleutians: Journal of Petrology, v. 56, n. 3, p. 441-492. http://doi:10.1093/petrology/egv006 


\section{APPENDIX 1. NOTES TO BE APPLIED TO THE GEOCHEMICAL DATA AND SAMPLE DESCRIPTIONS SPREADSHEET (SEE DIGITAL DATA ATTACHMENT)}

All sample data and metadata are provided in accompanying spreadsheets. The following notes apply:

- Major element analyses by XRF spectroscopy at the GeoAnalytical Laboratory, Washington State University (WSU). All oxides are normalized to $100 \%$, and the original analytical total is reported.

- Trace element analyses by XRF at the GeoAnalytical Laboratory, Washington State University, have element symbols with “_x” appended.

- $\mathrm{Cl}$ concentrations are minimum values.

- Trace element analyses by ICP/MS at the GeoAnalytical Laboratory, Washington State University, have element symbols with “_i” appended.

- Sample descriptions and location information are in last two columns.

- An estimate of analytical precision is given below (see Appendix 3 for details). Precision is indicated by the difference in measured concentration for each element in duplicate pellets or solutions prepared from a single powder and analyzed in the same run, in percent of the mean. The values given are greater than or equal to $95 \%$ of individual duplicate analyses. ICP/MS precision is independent of concentration over the range of sample compositions of the samples. $\mathrm{Ni}, \mathrm{Cr}$, and $\mathrm{Nb}$ determinations by XRF have lower precision at low concentrations.

\begin{tabular}{|c|c|c|c|}
\hline Element & Precision (\%) & Element & Precision (\%) \\
\hline $\mathrm{SiO}_{2}$ & 0.29 & La_i & 2.6 \\
\hline $\mathrm{TiO}_{2}$ & 0.90 & $\mathrm{Ce}_{-}^{-} \mathrm{i}$ & 3.2 \\
\hline $\mathrm{Al}_{2} \mathrm{O}_{3}$ & 0.52 & $\operatorname{Pr} \_\bar{i}$ & 3.8 \\
\hline $\mathrm{FeO} *$ & 2.7 & $\mathrm{Nd}_{-} \mathrm{i}$ & 3.9 \\
\hline $\mathrm{MnO}$ & 1.1 & $\mathrm{Sm}_{-} \mathrm{i}$ & 3.3 \\
\hline $\mathrm{MgO}$ & 1.4 & $\mathrm{Eu}_{-} \mathrm{i}$ & 3.6 \\
\hline $\mathrm{CaO}$ & 0.52 & $\mathrm{Gd}_{-} \mathrm{i}$ & 3.2 \\
\hline $\mathrm{Na}_{2} \mathrm{O}$ & 1.3 & $\mathrm{~Tb} \_\bar{i}$ & 3.3 \\
\hline $\mathrm{K}_{2} \mathrm{O}$ & 1.0 & $\mathrm{Dy}_{-} \mathrm{i}$ & 3.7 \\
\hline $\mathrm{P}_{2} \mathrm{O}_{5}$ & 2.0 & Ho_i & 2.9 \\
\hline Ni_x<10 ppm & 67 & $\mathrm{Er}_{-} \mathrm{i}$ & 3.2 \\
\hline Ni_x>10 ppm & 25 & $\operatorname{Tm}_{-} \mathrm{i}$ & 3.7 \\
\hline $\mathrm{Cr}_{-} \mathrm{x}<10 \mathrm{ppm}$ & 96 & $Y b_{-} \bar{i}$ & 3.5 \\
\hline $\mathrm{Cr}_{-} \mathrm{x}>10 \mathrm{ppm}$ & 25 & Lu_i & 3.5 \\
\hline Sc_x & 7.5 & $\mathrm{Ba}_{-} \mathrm{i}$ & 2.0 \\
\hline$v_{-} \bar{x}$ & 3.0 & $\mathrm{Th}$ & 6.3 \\
\hline $\mathrm{Ba}_{-} \mathrm{x}$ & 2.3 & $\mathrm{Nb}_{-}{ }_{-}^{\mathrm{i}}$ & 5.8 \\
\hline $\mathrm{Rb}_{-} \mathrm{x}$ & 8.7 & $Y_{-} i^{-}$ & 3.4 \\
\hline Sr_- $\bar{x}$ & 1.7 & $\mathrm{Hf}_{-} \mathrm{i}$ & 3.1 \\
\hline$Z r_{-} x$ & 2.8 & $\mathrm{Ta}_{-}^{-} \mathrm{i}$ & 8.4 \\
\hline$Y_{-} \bar{x}$ & 8.2 & $U_{-}{ }_{i}$ & 8.5 \\
\hline$\overline{N b} \_x<4$ ppm & 81 & $\mathrm{~Pb}_{-} \mathrm{i}^{-}$ & 5.3 \\
\hline $\mathrm{Nb}_{-} \mathrm{x}>4 \mathrm{ppm}$ & 14 & $\mathrm{Rb} \_\mathrm{i}$ & 3.4 \\
\hline Ga_x & 14 & $\mathrm{Cs}_{-} \overline{\mathrm{i}}$ & 7.9 \\
\hline $\mathrm{Cu}_{-}{ }^{\mathrm{x}}$ & 14 & $\mathrm{Sr}_{-}^{-} \mathrm{i}$ & 3.5 \\
\hline$Z n_{-}{ }^{\prime} x$ & 4.9 & $\mathrm{Sc}_{-}^{-} \mathrm{i}$ & 11 \\
\hline $\mathrm{Pb}_{-}{ }^{\mathrm{x}}$ & 50 & $\mathrm{Zr} \_\mathrm{i}$ & 3.1 \\
\hline La_- $x$ & 83 & & \\
\hline $\mathrm{Ce}_{-}^{-} \mathrm{x}$ & 38 & & \\
\hline Th_- $x$ & 105 & & \\
\hline $\mathrm{Nd}=x$ & 29 & & \\
\hline
\end{tabular}

- Most of the ICP/MS values have excess significant figures. Most elements analyzed by ICP have a total range of two or three orders of magnitude, so the number of significant figures for each element varies depending on concentration.

- Note the large imprecision of Pb_x, La_x, Ce_x, Th_x, and Nd_x analyses.

- n.a., not analyzed. 


\section{APPENDIX 2. ICP/MS CALIBRATION CHANGES: HISTORY AND CORRECTION}

Since 1990 there have been four calibration adjustments made to the reduction of ICP/MS intensity data at the GeoAnalytical Laboratory at Washington State University, where all data included in the report were generated. The changes between calibrations are given in table A2.1. All data in this report have been renormalized to the current calibration to insure internal consistency of the data. All published WSU ICP/MS data in the AVO database (available at https://www.avo.alaska.edu/geochem/) have also been corrected (Cameron and other, 2014). The reader should be aware that all data published or released in theses prior to 2007 have not been corrected, and therefore concentrations of some elements will be slightly different than those in the AVO database.

Correction of legacy data is made by multiplying the original concentrations by the correction factor to obtain the preferred concentrations. Correction factors are independent of concentration over the range of concentrations in AVO samples, which extend to chondritic levels in the most depleted cumulate inclusions.

\begin{tabular}{|c|c|c|c|c|}
\hline $\begin{array}{l}\text { from } \\
\text { through }\end{array}$ & $\begin{array}{c}1 \text { July, } 2006 \\
1 \text { March, } 2007\end{array}$ & $\begin{array}{c}26 \text { March, } 1998 \\
1 \text { July, } 2006\end{array}$ & $\begin{array}{c}8 \text { July, } 1995 \\
26 \text { March, } 1998\end{array}$ & $\begin{array}{c}1 \text { January, } 1990 \\
8 \text { July, } 1995\end{array}$ \\
\hline La & 1 & 0.99279 & 0.99275 & 0.99280 \\
\hline $\mathrm{Ce}$ & 1 & 1.04860 & 1.04858 & 1.04840 \\
\hline $\mathrm{Pr}$ & 1 & 1.11270 & 1.11264 & 1.11261 \\
\hline $\mathrm{Nd}$ & 1 & 1.07368 & 1.07385 & 1.07399 \\
\hline Sm & 1 & 1 & 1 & 1 \\
\hline $\mathrm{Eu}$ & 1 & 1.00191 & 1.00155 & 1.00180 \\
\hline $\mathrm{Gd}$ & 1 & 1 & 1 & 1.05197 \\
\hline Tb & 1 & 1 & 1 & 1 \\
\hline Dy & 1 & 1 & 1 & 1 \\
\hline Ho & 1 & 1 & 1 & 1 \\
\hline $\mathrm{Er}$ & 1 & 1 & 1 & 0.95015 \\
\hline $\mathrm{Tm}$ & 1 & 1 & 1 & 1 \\
\hline $\mathrm{Yb}$ & 1 & 1 & 1 & 1 \\
\hline Lu & 1 & 1 & 1 & 1 \\
\hline $\mathrm{Ba}$ & 1 & 1 & 1.02387 & 1.02389 \\
\hline Th & 1 & 1 & 1.18624 & 1.18629 \\
\hline $\mathrm{Nb}$ & 1 & 0.94927 & 0.94928 & 0.89921 \\
\hline Y & 1 & 0.95064 & 0.95013 & 0.95042 \\
\hline $\mathrm{Hf}$ & 1 & 1 & 1 & 1.06169 \\
\hline $\mathrm{Ta}$ & 1 & 0.95054 & 0.94984 & 0.97454 \\
\hline U & 1.05812 & 1.05807 & 1.05814 & 1.47506 \\
\hline $\mathrm{Pb}$ & 1 & 1 & 1 & 1 \\
\hline $\mathrm{Rb}$ & 1 & 1 & 1 & 1 \\
\hline Cs & 1 & 1 & 1 & 1 \\
\hline $\mathrm{Sr}$ & 1 & 1 & 1 & 1 \\
\hline Sc & 0.88802 & 0.88807 & 0.88805 & $\langle n d>$ \\
\hline $\mathrm{Zr}$ & 1 & 1 & 1 & $\langle\mathrm{nd}\rangle$ \\
\hline
\end{tabular}




\section{APPENDIX 3. ANALYTICAL PRECISION}

The following section is repeated from Nye and others (2017) for the convenience of the reader. During analysis duplicate pellets (XRF) or solutions (ICP/MS) are made from a single powder from one sample in each batch, or one sample in every twenty from batches with more than twenty unknowns. Comparison of elemental concentrations measured from each of the duplicates provides an estimate of analytical uncertainty which includes both machine precision and pellet or solution preparation uncertainty. Uncertainties associated with producing powder from a rock sample, or taking a small sample from an outcrop are not included. Here we discuss the distribution of intra-analysis variations for all duplicates from AVO samples analyzed at the GeoAnalytic Laboratory (Washington State University) between 2004 and 2016 (105 XRF duplicates and 131 ICP/MS duplicates).

Between-duplicate variations are calculated as absolute difference between duplicates divided by the mean of the two values, in percent $\left(100^{*}(|\mathrm{a}-\mathrm{b}| / 0.5(\mathrm{a}+\mathrm{b}))\right)$. An alternative method, not used here, would be to use the coefficient of variance between duplicates $\left(\mathrm{CV} ; 100^{\star}(1 \mathrm{std} / \mathrm{mean})\right.$, which yields results that are about $30 \%$ lower.

Comparing duplicates using the differences between analyses rather than the absolute differences yields a range of values for each element which are roughly normally distributed about a value near zero. However it's irrelevant if one analysis or the other has the larger value, so the mean of values based on arithmetic differences has no significance in terms of analytical precision. Calculating differences between duplicates using absolute variation (or, alternatively, CV) yields populations that are no-longer normally distributed because values that were negative are reflected to the positive side of distributions. Thus the range of inter-duplicate values cannot be summarized using its mean and standard deviation. Instead we summarize variations by percentiles, which can be asymmetric about the median value (Table A3.1). The 50th percentile (median) is the value where half the values are smaller and half larger. The 68th percentile is the value where the portion of the population with smaller intra-pellet variations is roughly equivalent to $\pm 1 \sigma$ of a normally distributed population, and the 95 th percentile is roughly equivalent to $\pm 2 \sigma$. Table A3.1 also gives the compositional range of the samples.

Table A3.1. Summary of intra-duplicate variation and compositional range of AVO samples analyzed by the Washington State University GeoAnalytical Laboratory between 2004 and 2016. Intra-duplicate variation is calculated as absolute difference divided by the average of the two values, in percent, and provides a measure of analytical precision (Table A5c.1, Nye and others [2017])

\begin{tabular}{|c|c|c|c|c|c|c|c|}
\hline \multirow{2}{*}{ element } & \multicolumn{2}{|c|}{ Concentration range } & \multirow{2}{*}{$\mathbf{n}$} & \multicolumn{4}{|c|}{$\begin{array}{c}\text { Percentile within distribution of relative percent variation between } \\
\text { duplicates }\end{array}$} \\
\hline & $\min$ & $\max$ & & $50 \%$ & $68 \%$ & $95 \%$ & $\max$ \\
\hline \multicolumn{8}{|c|}{ Major oxides (wt. \%) and trace elements (ppm) by XRF } \\
\hline $\mathrm{SiO}_{2}$ & 39.5 & 74.6 & 105 & 0.09 & 0.11 & 0.29 & 0.72 \\
\hline $\mathrm{TiO}_{2}$ & 0.138 & 2.21 & 105 & 0.23 & 0.32 & 0.90 & 1.4 \\
\hline $\mathrm{Al}_{2} \mathrm{O}_{3}$ & 12.2 & 22.3 & 105 & 0.15 & 0.23 & 0.52 & 0.94 \\
\hline $\mathrm{FeO} *$ & 1.45 & 18.9 & 105 & 0.70 & 1.2 & 2.7 & 6.0 \\
\hline $\mathrm{MnO}$ & 0.052 & 0.245 & 105 & 0.33 & 0.54 & 1.1 & 1.4 \\
\hline $\mathrm{MgO}$ & 0.553 & 13.5 & 105 & 0.37 & 0.46 & 1.4 & 2.9 \\
\hline $\mathrm{CaO}$ & 0.903 & 15.7 & 105 & 0.20 & 0.27 & 0.52 & 0.79 \\
\hline $\mathrm{Na}_{2} \mathrm{O}$ & 1.09 & 4.85 & 105 & 0.29 & 0.47 & 1.3 & 2.2 \\
\hline $\mathrm{K}_{2} \mathrm{O}$ & 0.084 & 3.85 & 105 & 0.27 & 0.40 & 1.0 & 2.2 \\
\hline $\mathrm{P}_{2} \mathrm{O}_{5}$ & 0.023 & 0.529 & 105 & 0.35 & 0.51 & 2.0 & 4.5 \\
\hline $\mathrm{Ni}$ & 1.2 & 114 & 102 & 6.1 & 11 & 55 & 88 \\
\hline $\mathrm{Ni}<10 \mathrm{ppm}$ & & & 50 & 13 & 38 & 67 & 88 \\
\hline $\mathrm{Ni}>10 \mathrm{ppm}$ & & & 52 & 4.2 & 7.0 & 25 & 38 \\
\hline
\end{tabular}




\begin{tabular}{|c|c|c|c|c|c|c|c|}
\hline \multirow[t]{2}{*}{ element } & \multicolumn{2}{|c|}{ Concentration range } & \multirow[t]{2}{*}{$\mathbf{n}$} & \multicolumn{4}{|c|}{$\begin{array}{c}\text { Percentile within distribution of relative percent variation between } \\
\text { duplicates }\end{array}$} \\
\hline & $\min$ & $\max$ & & $50 \%$ & $68 \%$ & $95 \%$ & $\max$ \\
\hline $\mathrm{Cr}$ & 0.54 & 300 & 101 & 4.7 & 11 & 69 & 100 \\
\hline$C_{r}<10 \mathrm{ppm}$ & & & 41 & 13 & 30 & 96 & 100 \\
\hline $\mathrm{Cr}>10 \mathrm{ppm}$ & & & 60 & 2.5 & 4.2 & 25 & 30 \\
\hline Sc & 4.4 & 81 & 105 & 2.3 & 3.5 & 7.5 & 30 \\
\hline $\mathrm{V}$ & 12 & 732 & 105 & 1.0 & 1.5 & 3.0 & 8.7 \\
\hline $\mathrm{Ba}$ & 63 & 1699 & 105 & 0.72 & 1.2 & 2.3 & 3.7 \\
\hline $\mathrm{Rb}$ & 1.1 & 80 & 105 & 2.0 & 2.8 & 8.7 & 33 \\
\hline $\mathrm{Sr}$ & 143 & 1082 & 105 & 0.39 & 0.62 & 1.7 & 2.7 \\
\hline $\mathrm{Zr}$ & 11 & 267 & 105 & 0.66 & 0.91 & 2.8 & 6.1 \\
\hline $\mathrm{Y}$ & 9.0 & 49 & 104 & 1.6 & 2.8 & 8.2 & 19 \\
\hline $\mathrm{Nb}$ & 0.35 & 13 & 104 & 10 & 13 & 54 & 100 \\
\hline$N b<4$ ppm & & & 54 & 16 & 24 & 81 & 100 \\
\hline$N b>4 \mathrm{ppm}$ & & & 50 & 5.4 & 8.6 & 14 & 27 \\
\hline $\mathrm{Ga}$ & 16 & 23 & 105 & 3.7 & 5.4 & 14 & 27 \\
\hline $\mathrm{Cu}$ & 1.9 & 256 & 104 & 1.7 & 2.7 & 14 & 52 \\
\hline $\mathrm{Zn}$ & 42 & 118 & 105 & 1.2 & 2.2 & 4.9 & 6.0 \\
\hline $\mathrm{Pb}$ & 0.90 & 18 & 104 & 8.2 & 15 & 50 & 136 \\
\hline La & 1.5 & 30 & 105 & 16 & 22 & 83 & 144 \\
\hline $\mathrm{Ce}$ & 5.7 & 71 & 105 & 9.9 & 15 & 38 & 90 \\
\hline Th & 0.20 & 8.4 & 100 & 20 & 32 & 105 & 179 \\
\hline $\mathrm{Nd}$ & 4.2 & 40 & 85 & 9.8 & 13 & 29 & 37 \\
\hline $\mathrm{U}$ & 0.35 & 3.9 & 41 & 48 & 72 & 140 & 141 \\
\hline \multicolumn{8}{|c|}{ Trace elements (ppm) by ICP/MS } \\
\hline La & 1.2 & 30 & 131 & 0.80 & 1.2 & 2.6 & 8.4 \\
\hline $\mathrm{Ce}$ & 3.2 & 67 & 131 & 0.76 & 1.1 & 3.2 & 7.8 \\
\hline $\operatorname{Pr}$ & 0.54 & 9.2 & 131 & 0.78 & 1.2 & 3.8 & 12 \\
\hline $\mathrm{Nd}$ & 3.0 & 40 & 131 & 0.86 & 1.3 & 3.9 & 8.5 \\
\hline $\mathrm{Sm}$ & 1.1 & 9.8 & 131 & 1.3 & 1.9 & 3.3 & 4.2 \\
\hline $\mathrm{Eu}$ & 0.49 & 2.5 & 131 & 1.4 & 2.1 & 3.6 & 5.4 \\
\hline $\mathrm{Gd}$ & 1.4 & 9.8 & 131 & 1.4 & 1.8 & 3.2 & 4.0 \\
\hline $\mathrm{Tb}$ & 0.25 & 1.6 & 131 & 1.0 & 1.6 & 3.3 & 4.7 \\
\hline Dy & 1.5 & 10.0 & 131 & 1.1 & 1.6 & 3.7 & 5.3 \\
\hline $\mathrm{Ho}$ & 0.29 & 2.1 & 131 & 1.0 & 1.5 & 2.9 & 6.1 \\
\hline $\mathrm{Er}$ & 0.75 & 5.9 & 131 & 0.94 & 1.3 & 3.2 & 4.8 \\
\hline $\mathrm{Tm}$ & 0.10 & 0.90 & 131 & 1.3 & 1.7 & 3.7 & 7.0 \\
\hline $\mathrm{Yb}$ & 0.61 & 5.8 & 131 & 1.3 & 1.8 & 3.5 & 5.5 \\
\hline Lu & 0.092 & 0.94 & 131 & 1.2 & 1.8 & 3.5 & 6.8 \\
\hline $\mathrm{Ba}$ & 57 & 1767 & 131 & 0.72 & 1.0 & 2.0 & 13 \\
\hline Th & 0.13 & 9.2 & 131 & 1.4 & 2.2 & 6.3 & 35 \\
\hline $\mathrm{Nb}$ & 0.28 & 12 & 131 & 1.3 & 1.9 & 5.8 & 53 \\
\hline$Y$ & 7.2 & 55 & 131 & 1.0 & 1.6 & 3.4 & 19 \\
\hline $\mathrm{Hf}$ & 0.26 & 9.8 & 131 & 1.2 & 1.5 & 3.1 & 6.5 \\
\hline $\mathrm{Ta}$ & 0.023 & 1.1 & 131 & 1.7 & 3.0 & 8.4 & 92 \\
\hline U & 0.078 & 4.1 & 131 & 1.4 & 2.1 & 8.5 & 47 \\
\hline $\mathrm{Pb}$ & 0.96 & 29 & 131 & 1.1 & 2.1 & 5.3 & 75 \\
\hline $\mathrm{Rb}$ & 1.0 & 97 & 131 & 1.4 & 1.8 & 3.4 & 7.0 \\
\hline Cs & 0.084 & 6.6 & 131 & 1.5 & 2.4 & 7.9 & 77 \\
\hline $\mathrm{Sr}$ & 149 & 1060 & 131 & 0.87 & 1.3 & 3.5 & 5.3 \\
\hline Sc & 3.6 & 44 & 131 & 2.4 & 3.9 & 11 & 16 \\
\hline $\mathrm{Zr}$ & 7.59 & 333 & 131 & 1.0 & 1.5 & 3.1 & 4.9 \\
\hline
\end{tabular}

It is also important to know if analytical precision is compositionally dependent (i. e. if lower concentrations of any element have systematically poorer precision). Figures A3.1-5 are plots of duplicate variation vs. concentration for all elements by both XRF and ICP/MS. Principle observations are:

Major element precision (Figure A3.1) is independent of composition and generally better than 0.5 rel. $\%$ at the $68^{\text {th }}$ percentile except for iron, which is about 1.2 rel. \%.

XRF analyses of $\mathrm{Ni}, \mathrm{Cr}$ and $\mathrm{Nb}$ (Figure A3.2) are generally better than 10 rel. \%, but increase systematically at concentrations below $10 \mathrm{ppm}(\mathrm{Ni}$ and $\mathrm{Cr}$ ) and $4 \mathrm{ppm}(\mathrm{Nb})$. Variations approach $100 \%$ 
(the detection limit) at about $2 \mathrm{ppm}(\mathrm{Ni}$ and $\mathrm{Cr}$ ) and $1 \mathrm{ppm}(\mathrm{Nb}) . \mathrm{Rb}$ and $\mathrm{Y}$ precision also decrease and disperses at low concentrations, but not as severely as $\mathrm{Ni}, \mathrm{Cr}$, and $\mathrm{Nb}$.

REE analyses by ICP/MS (Figure A3.3) have precisions of better than 2 rel.\% at the $68^{\text {th }}$ percentile; better than 4 rel. $\%$ at the $95^{\text {th }}$ percentile and are independent of concentration-as low as about 5 times chondritic concentrations in the data summarized here.

Analyses of trace elements other than REE by ICP/MS (Figure A3.4) have precisions similar to the REE, and are also independent of concentration with the exception of $\mathrm{Ta}$, $\mathrm{Cs}$, and $\mathrm{Pb}$ which have modest increased dispersion of variation below $0.2 \mathrm{ppm}(\mathrm{Ta}), 1.5 \mathrm{ppm}(\mathrm{Cs})$, and $8 \mathrm{ppm}(\mathrm{Pb})$.

Concentrations of a dozen trace elements are measured by both XRF and ICP/MS (Figure A3.5). Ba, $\mathrm{Rb}, \mathrm{Sr}$, and Zr have similar analytical precision by both techniques. Y precision by XRF and ICP/MS is similar at concentrations greater than $25 \mathrm{ppm}$, but at concentrations less than $25 \mathrm{ppm}$ the XRF data are somewhat less precise. For $\mathrm{Nb}, \mathrm{Pb}, \mathrm{Th}, \mathrm{La}, \mathrm{Ce}, \mathrm{Nd}$, and $\mathrm{U} \mathrm{XRF}$ precision is substantially poorer over most or all of the concentration range of AVO samples. ICP/MS analyses of $\mathrm{Pb}, \mathrm{Th}, \mathrm{La}, \mathrm{Ce}, \mathrm{Nd}$, and $\mathrm{U}$ should always be used when available.

In a small number of cases there are abnormally large variations between duplicates. About $1.3 \%$ of the data lie outside $3 \sigma$ of intra-duplicate variations calculated as the arithmetic difference divided by the mean of the two analyses. In most cases these outliers are widely separated from neighboring points when the data for each element are ranked by inter-duplicate variation. In the ranked data most neighboring points are less than $5 \%$ different, but in the tails of the distribution the difference between neighbors can increase to several hundreds of percent. In some cases the outliers are associated with the lowest-concentration of a particular element in the data set, but in many cases the outliers span the full concentration range of the data. For instance, Pr variation (Figure A3.2) is mostly less than $2 \%$, but in four cases the variation between duplicates is $9-13 \%$. Outliers generally exist only for one element in a given duplicate pair. There are no duplicate pairs where one analysis is systematically and uniformly different across many or all elements. The implication of the existence of the outliers is that for any large data set a few of the values for a few of the elements may be aberrant for reasons unrelated to geology, petrology, or geochemistry. 


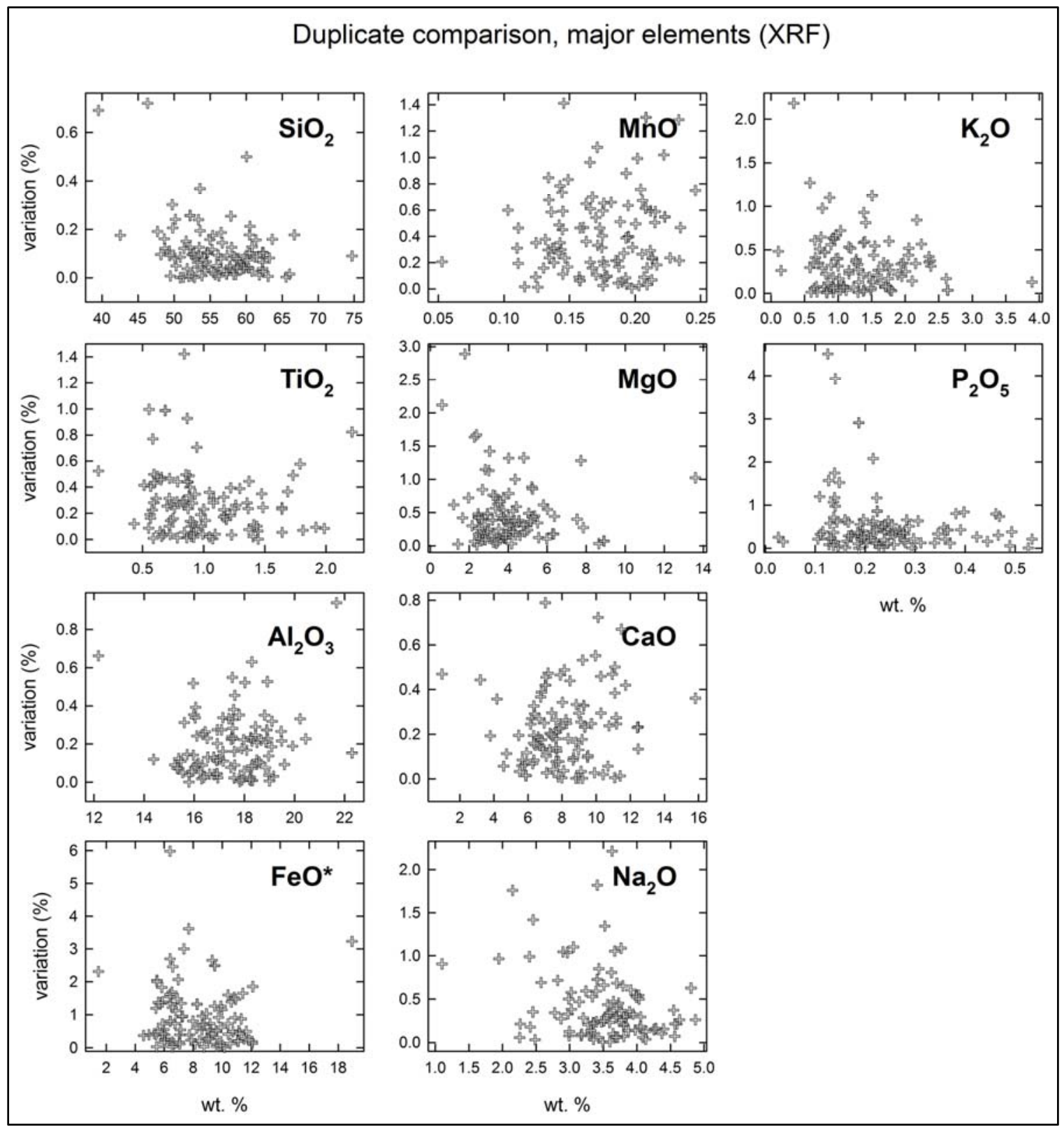

Figure A3.1. Variation between duplicate pellets vs. concentration for major elements (normalized to 100\%) measured by XRF. Variation is $100^{*}|a-b| /((a+b) / 2)$ (fig. A5c.1, Nye and others, 2017). 


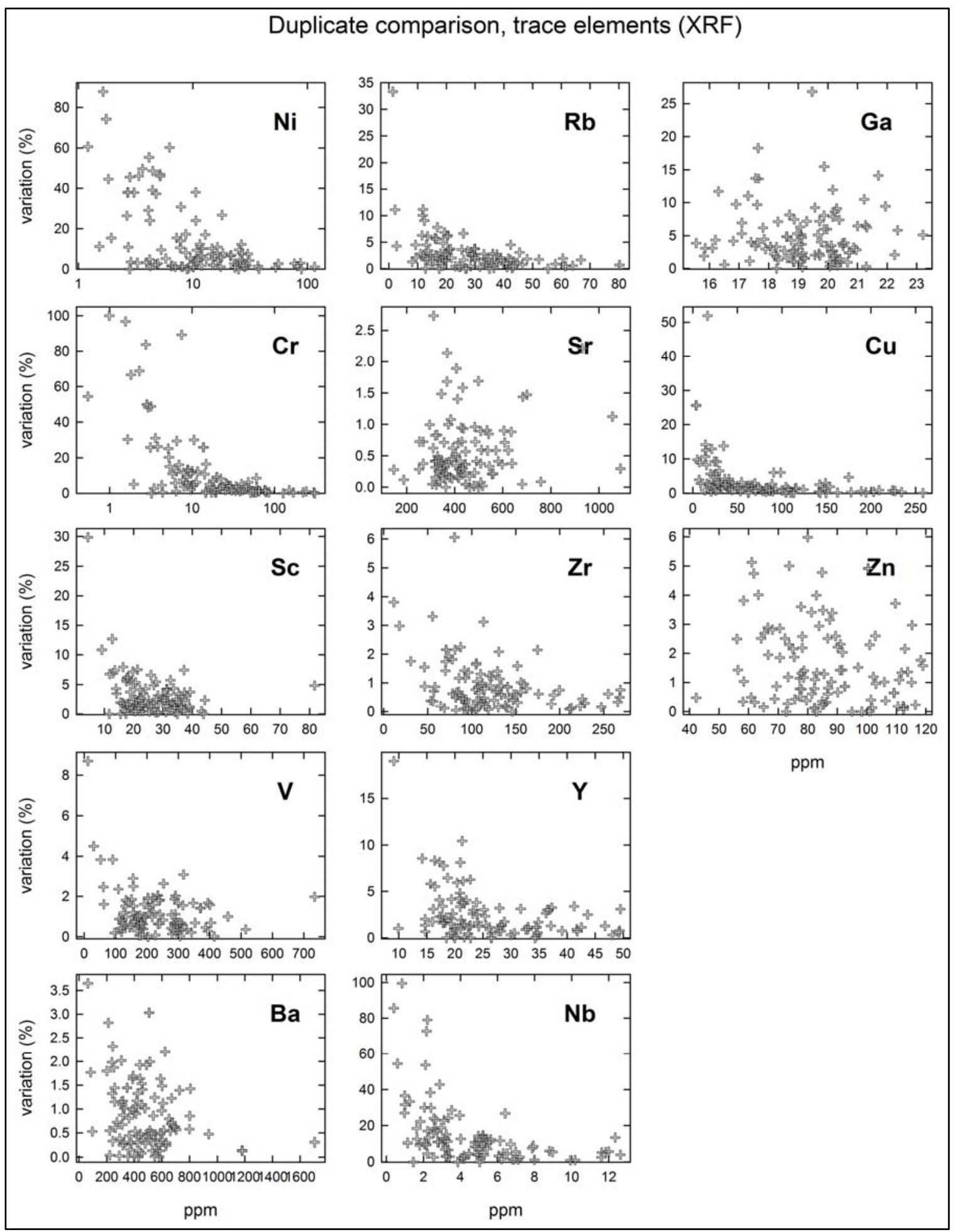

Figure A3.2. Variation between duplicate pellets vs. concentration for trace elements measured by XRF (fig. A5c.2, Nye and others, 2017). 


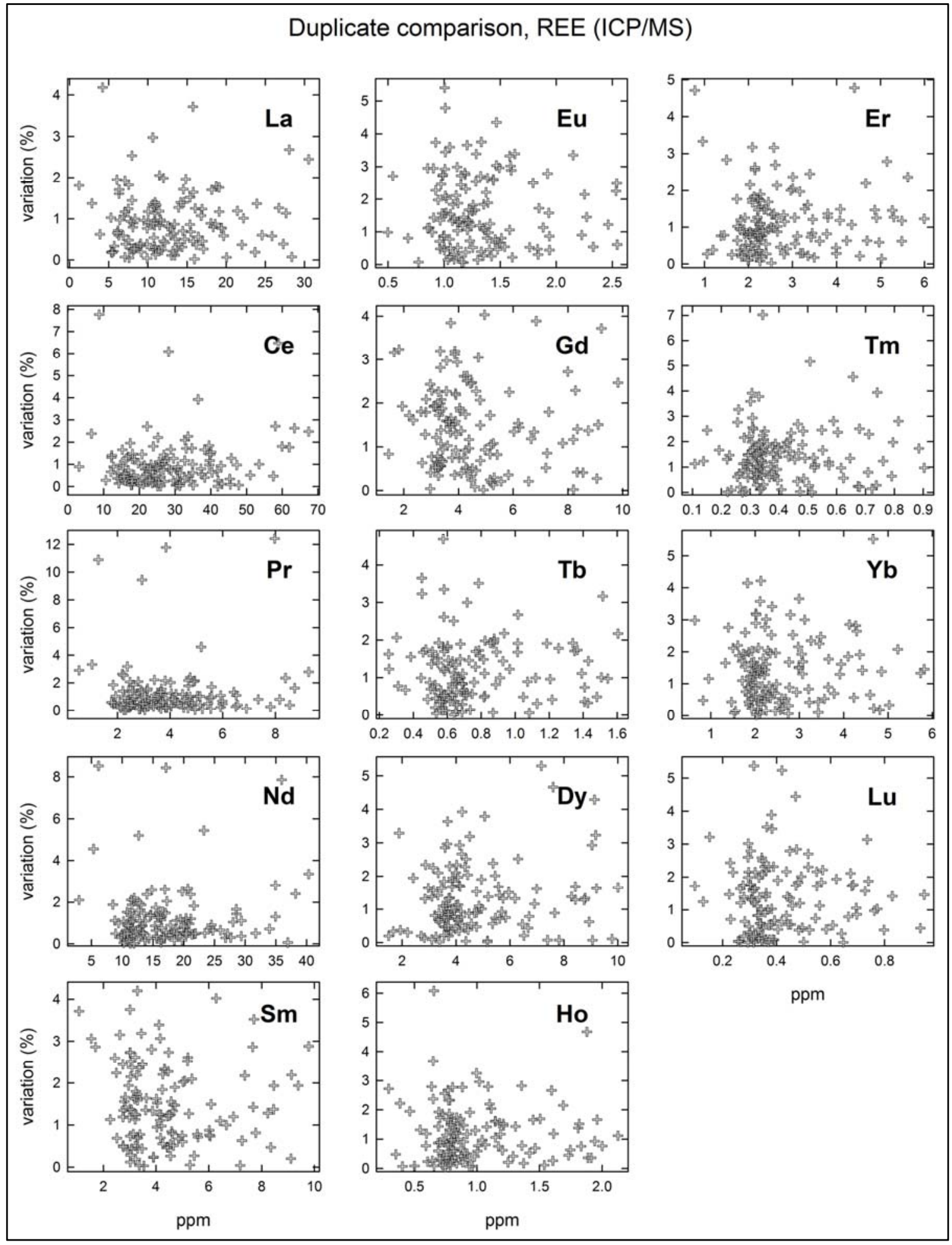

Figure A3.3. Variation between duplicate pellets vs. concentration for trace elements measured by XRF (fig. A5c.3, Nye and others, 2017). 


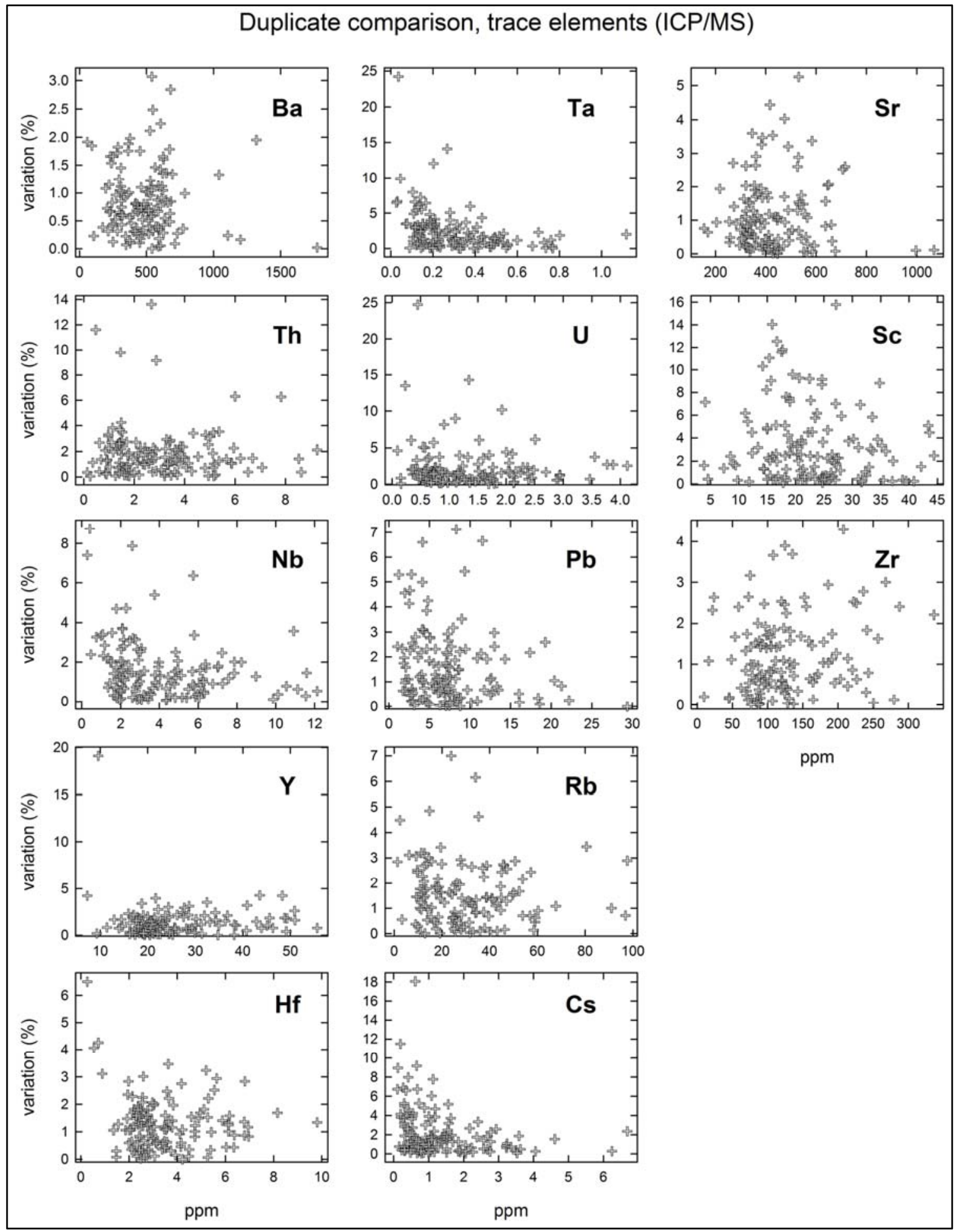

Figure A3.4. Variation between duplicate pellets vs. concentration for trace elements other than REE measured by ICP/MS (fig. A5c.4, Nye and others, 2017). 


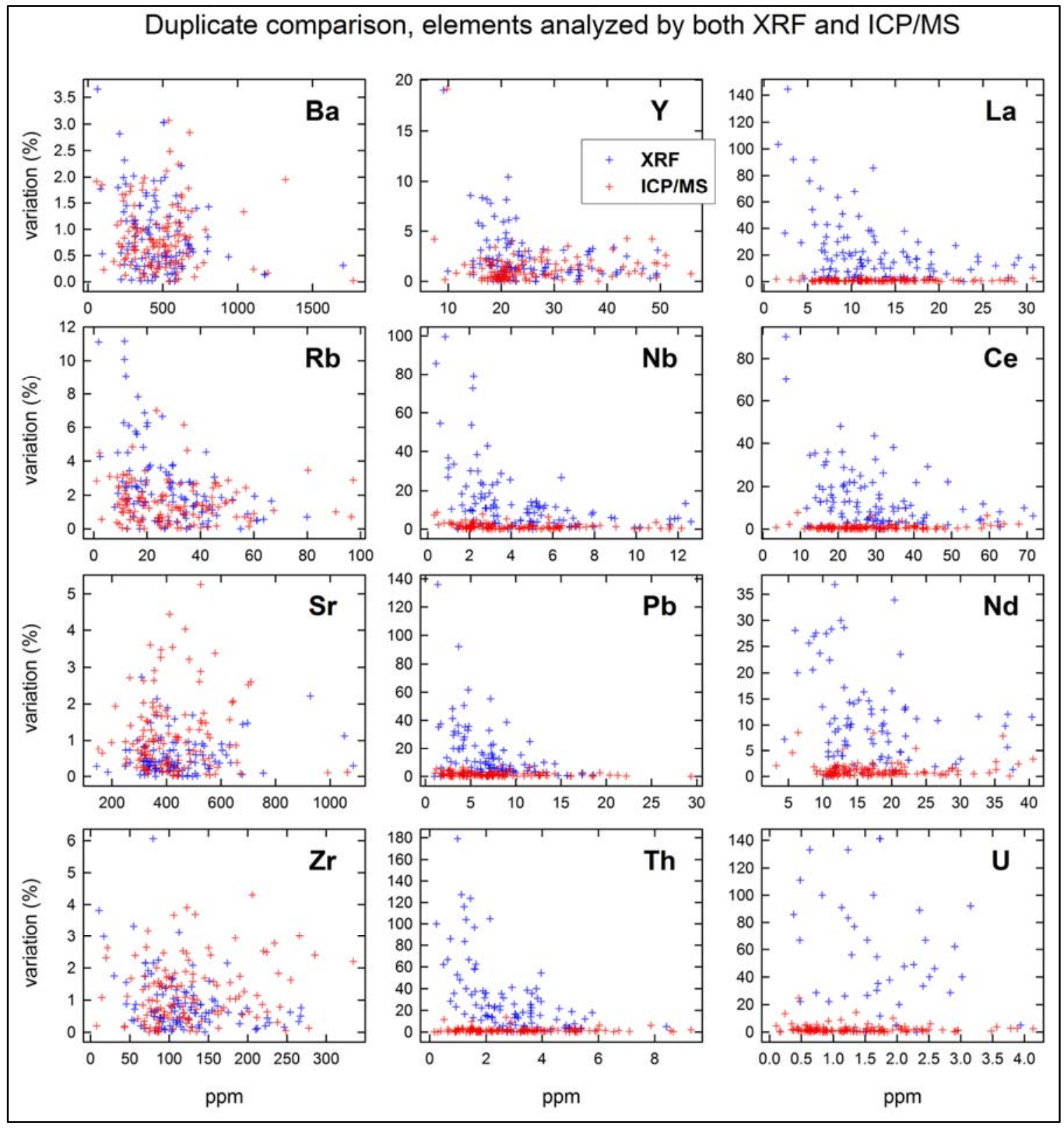

Figure A3.5. Variation between duplicate pellets vs. concentration for trace elements measured by both XRF and ICP/MS (fig. A5c.5, Nye and others, 2017). 